\title{
Leaching optimization of mining wastes with lizardite and brucite contents for use in indirect mineral carbonation through the $\mathrm{pH}$ swing method
}

\author{
Gretta L.A.F. Arce ${ }^{\text {a, b, * }}$, Turibio G. Soares Neto ${ }^{a}$, I. Ávila ${ }^{b}$, Carlos M.R. Luna ${ }^{b}$, \\ João A. Carvalho Jr. ${ }^{\text {b }}$ \\ ${ }^{a}$ INPE - National Institute for Space Research, Combustion and Propulsion Associated Laboratory, Rodovía Presidente Dutra, km 40, 12630-000, Cachoeira \\ Paulista, SP, Brazil \\ ${ }^{\mathrm{b}}$ UNESP - Univ Estadual Paulista, Guaratinguetá Engineering Campus, Department of Energy, Combustion and Carbon Capture Laboratory (LC 3 ), Av. Dr. \\ Ariberto Pereira da Cunha, 333, 12516-410, Guaratinguetá, SP, Brazil
}

\section{A R T I C L E I N F O}

\section{Article history:}

Received 9 February 2016

Received in revised form

27 September 2016

Accepted 27 September 2016

Available online 28 September 2016

\section{Keywords:}

Leaching

Mining waste

Lizardite

Brucite

Iron

Mineral carbonation

\begin{abstract}
A B S T R A C T
This study investigated the leaching process in order to maximize $\mathrm{Mg}$ and Fe extraction and to produce amorphous silica $\left(\mathrm{SiO}_{2}\right)$ with high purity. For this, a mining waste identified as $\mathrm{S}-\mathrm{GO}$ was employed; which is a serpentinite rock with high lizardite 1T and native brucite contents. A Taguchi Experiment Design was used in order to assess the parameters that influence the leaching process such as: granulometry, hydrochloric acid concentration $(\mathrm{HCl})$, leaching temperature, and mass/volume ratio. Furthermore, thermogravimetric analysis (TGA) was done to understand the interrelation between the mineral structure and leaching performance. Results show that lizardite 1T-bearing serpentinite presents a low content of tetrahedral $\mathrm{Al}^{3+}$ and high octahedral $\mathrm{Fe}^{3+}$ contents on S-GO. Native brucite delayed the formation of a hydrated silica layer and improved dissolution of serpentines. For this, $\mathrm{Mg}$ and $\mathrm{Fe}$ extractions are efficient, reaching $88 \pm 2 \%$ of $\mathrm{Mg}$ and Fe extracted during the first 30 min of reaction, under mild process conditions: stoichiometric mass/volume ratio, $1 \mathrm{M} \mathrm{HCl}$ concentration, pressure of 1 bar, temperature of $100{ }^{\circ} \mathrm{C}$, and $300 \mu \mathrm{m}$ particle size. On the other hand, an excess of acid improves $\mathrm{Mg}$ and $\mathrm{Fe}$ extraction by only $10 \pm 5 \%$ for S-GO. Such characteristics reduce energetic penalties and costs involved on indirect mineral carbonation processes by the $\mathrm{pH}$ swing method.
\end{abstract}

() 2016 Elsevier Ltd. All rights reserved.

\section{Introduction}

Increasing energy demands in developed and developing countries have caused concerns regarding anthropogenic $\mathrm{CO}_{2}$ emission into the atmosphere (Azdarpour et al., 2015). As a consequence, atmospheric $\mathrm{CO}_{2}$ concentration has been increasing with a rate of approximately 2 ppm per year, reaching concentrations of about 400 ppm in 2015 as forecast by Arce et al. (2014). This increase will very likely lead to irreversible harmful consequences (Highfield et al., 2012).

Carbon capture and storage by mineralization (CCSM) can significantly reduce impacts of climate change through $\mathrm{CO}_{2}$ capture

\footnotetext{
* Corresponding author. Brazilian Space Research Institute (INPE), Combustion and Propulsion Associated Laboratory (LCP), Rodovía Presidente Dutra, km 40, Cachoeira Paulista, SP CEP 12630-000, Brazil.
}

E-mail addresses: grettagaf@yahoo.es, grettagaf@lcp.inpe.br (G.L.A.F. Arce). and fixation into carbonates. These carbonates are environmentally stable and have been proven as a mean to store anthropogenic $\mathrm{CO}_{2}$ emissions. Thus, CCSM has presented a renewed industrial interest (Dlugogorski and Balucan, 2014; Sanna et al., 2014b).

There are currently two types of CCSM approaches: i) in situ or direct mineral carbonation and ii) ex-situ or indirect mineral carbonation. The suitability of direct mineral carbonation is controversial due to its technical feasibility on large scale, as a consequence of the low rate of reaction, long residence time, high pressure and temperature (Assima et al., 2014; Daval et al., 2013; Sanna et al., 2013).

Indirect mineral carbonation by the pH-swing method using silicate rocks is recently having more attention since it is kinetically favored and have a short reaction time (Azdarpour et al., 2015; Hemmati et al., 2014a; Sanna et al., 2014a). Several researches pointed out that the $\mathrm{pH}$-swing method allows formation and separation of high-purity commercial products (i.e. carbonates, silica, 
and iron oxides) (Hemmati et al., 2014a, 2014b; Sanna et al., 2013, 2014a,b). These products will necessarily have to be sold in order to reduce the high cost associated to the pH-swing method (Hemmati et al., 2014b).

The use of hydrochloric acid $(\mathrm{HCl})$ for the $\mathrm{pH}$ swing method is recognized by its efficiency on leaching materials such as olivines and chrysotiles (House et al., 2007; Teir et al., 2007a, 2007b). Several studies reported a high dissolution of olivines and chrysotiles in the first reaction hour (60-80\%) and a total dissolution in the second reaction hour (100\%). In addition, residence time in the reactor can be reduced, improving acid concentration and/or reducing particle size, which reduces the cost involved with the $\mathrm{pH}$ swing method (Bu et al., 2012; Teir et al., 2007b).

However, the main inconvenience of $\mathrm{HCl}$ is the energetic penalty involved with its recovery by electrolysis processes (Björklöf and Zevenhoven, 2012; House et al., 2007; Teir et al., 2009). Thus, recent researches (Hemmati et al., 2014a, 2014b), employed $\mathrm{HCl}$ considering its recovery by bipolar electrodialysis. According to the patent by Bu et al. (2012), the bipolar electrodialysis process can be done at environment temperature $\left(25^{\circ} \mathrm{C}\right)$, producing $1 \mathrm{M} \mathrm{HCl}$ and $\mathrm{NaOH}$ solutions. Required theoretical electricity consumption is between 372 and $560 \mathrm{~kW} \mathrm{h/tNaOH}$, which is lower than the value required by conventional electrolysis ( $1468 \mathrm{~kW} \mathrm{h/tNaOH})$, greatly reducing penalties involved in the $\mathrm{pH}$ swing method using $\mathrm{HCl}$.

As reported in previous studies, serpentines (i.e. antigorite, lizardite, and chrysotile) commonly used on indirect mineral carbonation by the $\mathrm{pH}$ swing method, present different reactivity although they have similar chemical composition $\left(\mathrm{Mg}_{3} \mathrm{Si}_{2} \mathrm{O}_{5}(\mathrm{OH})_{4}\right)$. Conflicting results were observed regarding the efficiency of $\mathrm{Mg}$ and $\mathrm{Fe}$ extraction for several serpentines. For example, when lizardite is employed (Daval et al., 2013; Sanna et al., 2013), lower Mg and Fe extraction is reached in comparison to antigorite (Maroto-Valer and Kuchta, 2004; Park and Fan, 2004; Van Essendelft and Schobert, 2009) and chrysotile (McCutcheon et al., 2015; Teir et al., 2007b).

Based on these results when used strong acids (Table 1 ), the readiness to extract $\mathrm{Mg}$ and $\mathrm{Fe}$ from serpentines presents the following order: chrysotiles > antigorites > lizardites. However, recent studies indicated that lizardites present best $\mathrm{Mg}$ extraction rates due to the low $\mathrm{Al}$ content within its structure (Lacinska et al., 2016). On the other hand, Lavikko and Eklund (2016) reported that the original hypothesis of lizardite being more suitable for indirect mineral carbonation than antigorite was not absolutely correct, stating that some parameters such as parent rock and later transformation of the rock through metamorphosis or other type of alteration need to be taken into consideration. This suggests that all those parameters and serpentinite mineral structure are important aspects to evaluate its feasibility as raw material on indirect mineral carbonation processes.

A dry method is normally used in the asbestos fiber production to separate and classify fibers. Two types of residue are obtained from this method: mining (sterile or mining waste) and milling (tailing) residues. The first residue is composed of oversized rocks from the mining process and it is called sterile, due to the low chrysotile content (or fiber), but high levels of other minerals are found such as: lizardites, antigorites, brucites, olivines, and piroxene, among others. Steriles are currently disposed of on landfills, following safety regulations (Stewart et al., 1977). According to Li et al. (2014), Nam et al. (2014), and Valouma et al. (2016), this final disposal method does not guarantee the destruction of the asbestiform structure of the chrysotile. Moreover, as stated in Habashi, (2002), approximately 20 tons of waste rocks (or sterile) must be removed for each chrysotile ton produced. In this manner, employment of sterile as raw material for indirect mineral carbonation is relevant due to its high $\mathrm{MgO}$ levels.

The use of mining residues from production of asbestos fibers (sterile) employing indirect mineral carbonation has been insufficiently explored, since their study is done with tailing residues characterized by high content of serpentines. However, such tailings rarely present mixtures with other minerals of simpler structure (i.e. brucite) as presented on Table 1. Steriles and tailings with native brucite contents are normally studied in direct mineral carbonation for atmospheric $\mathrm{CO}_{2}$ capture (Assima et al., 2014, 2013, 2012; Harrison et al., 2013). Recent studies regarding direct mineral carbonation demonstrated that efficiency of capturing mining residues is improved when native brucite content is increased. Nevertheless, compact serpentines (lizardites/antigorites) with high $\mathrm{Si}$ and Fe contents (mainly $\mathrm{Fe}^{3+}$ ) were less appropriate due to passivation mechanisms (silica gel formation and acidification of the reaction medium) limiting formation of carbonates (Assima et al., 2014, 2013, 2012; Harrison et al., 2013).

Thus, this research has the objective of evaluating the leaching process of a mining waste from production of asbestos fibers (sterile), which presents contents of lizardite and native brucite. This evaluation considers mineralogical complexity and crystal chemistry for different reaction parameters which aims to maximize $\mathrm{Mg}$ and Fe extraction, as well as the purity of the silica produced. In order to accomplish this, experiment design (DoE) based on the Taguchi method was employed to evaluate the effect of parameters that might influence leaching.

The following parameters were investigated: material granulometry, leaching agent concentration, leaching temperature, and excess of leaching agent. Concentration and excess of leaching agent were evaluated in order to reduce costs and penalties involved with acid usage; however without impairing leaching efficiency.

\subsection{Serpentines: phases and structure}

There are different polymorphous serpentines (i.e. antigorites, lizardites, and chrysotiles) presenting sheets with octahedral $\mathrm{Mg}^{2+}$

Table 1

Published results for leaching processes using strong acids by indirect mineral carbonation.

\begin{tabular}{|c|c|c|c|c|c|c|c|c|c|c|}
\hline \multirow[t]{2}{*}{ Silicate rocks } & \multirow[t]{2}{*}{ Minerals } & \multirow[t]{2}{*}{$\% \mathrm{Mg}$ extracted } & \multirow[t]{2}{*}{ Acid } & \multirow[t]{2}{*}{ Conditions } & \multicolumn{5}{|c|}{ Characteristics } & \multirow[t]{2}{*}{ References } \\
\hline & & & & & BET $\mathrm{m}^{2} / \mathrm{g}$ & $\mathrm{PS} \mu \mathrm{m}$ & $\mathrm{Mg} \%$ & $\mathrm{Ca} \%$ & Si \% & \\
\hline Serpentinite & Lizardite & 9 & $\mathrm{HCl}$ & $1 \mathrm{M}, 90{ }^{\circ} \mathrm{C}, 2 \mathrm{~h}$ & 7.2 & $500-800$ & 24.5 & n.r. & 19.7 & (Daval et al., 2013) \\
\hline Serpentinite & Antigorite & 40 & $\mathrm{HCl}$ & $1 \mathrm{M}, 70^{\circ} \mathrm{C}, 5 \mathrm{~h}$ & 4.2 & 37 & 27.1 & n.r. & 20.1 & (Park and Fan, 2004) \\
\hline \multirow{2}{*}{ Serpentinite $^{a}$} & Chrysotile antigorite lizardite & 100 & $\mathrm{HCl}$ & $2 \mathrm{M}, 70{ }^{\circ} \mathrm{C}, 2 \mathrm{~h}$ & 27.9 & $75-150$ & 21.83 & 0.34 & 11.59 & (Teir et al., 2007a) \\
\hline & & 80 & & $2 \mathrm{M}, 70^{\circ} \mathrm{C}, 2 \mathrm{~h}$ & n.r. & $300-500$ & & & & \\
\hline Serpentinite & Antigorite forsterite & 98 & $\mathrm{NH}_{4} \mathrm{HSO}_{4}$ & $1.4 \mathrm{M}, 100^{\circ} \mathrm{C}, 3 \mathrm{~h}$ & n.r. & $75-150$ & 24.28 & 0.07 & 17.81 & (Wang and Maroto-valer, 2011) \\
\hline Serpentinite & Lizardite calcite & 70 & $\mathrm{NH}_{4} \mathrm{HSO}_{4}$ & $1.4 \mathrm{M}, 100^{\circ} \mathrm{C}, 3 \mathrm{~h}$ & n.r. & $75-150$ & 29 & 0.3 & 19.6 & (Sanna et al., 2014a,b) \\
\hline Serpentinite & Antigorite lizardite verculite & 20 & $\mathrm{H}_{2} \mathrm{SO}_{4}$ & $1 \mathrm{M}, 50^{\circ} \mathrm{C}, 2 \mathrm{~h}$ & n.r. & 90 & 23.7 & 0.3 & 17.57 & (Van Essendelft and Schobert, 2009) \\
\hline Serpentinite & Antigorite lizardite verculite & 70 & $\mathrm{H}_{2} \mathrm{SO}_{4}$ & $5 \mathrm{M}, 75^{\circ} \mathrm{C}, 2 \mathrm{~h}$ & n.r. & 38 & 23.7 & 0.3 & 17.57 & \\
\hline
\end{tabular}

n.r. = not reported

${ }^{a} \mathrm{Mg}, \mathrm{Ca}$, and Si values are the average between the XRF and ICP-OES data, provided by the authors. 
(O) and tetrahedral $\mathrm{Si}^{4+}(\mathrm{T})$, organized into 1:1 layers that form wavy, flat, and concentric structures, respectively. There is a space for Van Der Waals bonds among O-T layers. Fig. 1 presents serpentine polymorphisms and the disorder effect between tetrahedral $(\mathrm{T})$ and octahedral $(\mathrm{O})$ layers.

Each polymorphous subgroup have several polytypes which depend on the cationic replacement mechanism (Wicks and Whittaker, 1975). This mechanism is characterized by the exchange between octahedral $\mathrm{Mg}^{2+}(\mathrm{O})$ and tetrahedral $\mathrm{Si}^{4+}(\mathrm{T})$ with $\mathrm{Al}^{3+}, \mathrm{Fe}^{3+}$, and $\mathrm{Fe}^{2+}$. Such cation replacement causes a deficit of positive charges and excess of negative charges between octahedral and tetrahedral sheets, respectively, determining the disorder level and serpentine structural instability (Chamley, 1989; Putnis, 2003; Wicks and Whittaker, 1975).

Thus, octahedral $\mathrm{Mg}^{2+}(\mathrm{O})$ can be replaced by $\mathrm{Al}^{3+}, \mathrm{Fe}^{3+}$, and $\mathrm{Fe}^{2+}$, while tetrahedral $\mathrm{Si}^{4+}(\mathrm{T})$ can mainly be replaced by $\mathrm{Al}^{3+}$, and sometimes by $\mathrm{Fe}^{3+}$. Replacement by $\mathrm{Fe}^{3+}$ within tetrahedral $(\mathrm{T})$ and octahedral $(\mathrm{O})$ sheets have the same effect than replacement by $\mathrm{Al}^{3+}$, causing the serpentine to be more ordered and stable. However, this replacement is less effective when done in the octahedral sheet (O) (Caruso and Chernosky, 1979; Mellini, 1982; Trittschack et al., 2014; Wicks and Whittaker, 1975).

\section{Material and methods}

\subsection{Materials}

The Minaçu Mine sterile identified as S-GO was selected for this study, which is located at Cana Brava, Goiás State - Brazil. It was provided in the form of rocks with average dimensions of $31.0 \times 15.5 \mathrm{~cm}$. A ball crusher was used in order to reduce its size. Then, rocks were ground in a jar mill with different size alumina spheres, during approximately $18 \mathrm{~h}$, at a $350 \mathrm{rpm}$ angle speed.

Particle size was classified for S-GO characterization analysis using an ASTM 200 mesh $(75 \mu \mathrm{m})$ and a 270 mesh $(53 \mu \mathrm{m})$, so that the fraction had grains between both sizes. Several particle sizes were classified for the experimental DoE test. In order to obtain $75 \mu \mathrm{m}, 150 \mu \mathrm{m}$, and $300 \mu \mathrm{m}$ particle sizes, ASTM mesh numbers equivalent to $230-170,120-80$, and $60-45$ were used, respectively.

In order to characterize a clinochrysotile decomposition DTG peak, a clinochrysotile sample of high purity was employed, identified as SS. This sample came from Minaçu Mine (Goiás State) and it refers to fibers removed from Tailings. The SS fiber size was equivalent to $710 \mu \mathrm{m}$ and it was used to perform a thermal decomposition analysis.

\subsection{Leaching process experiments}

Mass/volume ratio employed for all experimental tests was equivalent to $37 \mathrm{~g} / \mathrm{L}$. The S-GO powder and acid solution were inserted into a $500 \mathrm{~mL}$ reactor vessel. Acid solutions were initially inserted into the reactor vessel and heated to a specific temperature for each DoE experimental test. S-GO powder was added to the reactor vessel once the acid solution was heated.
The reactor vessel was equipped with a Graham condenser in order to avoid $\mathrm{HCl}$ loss by evaporation, as well as a heater with a thermocouple for temperature control. The vessel was continuously agitated with a magnetic stirrer set at 600-700 rpm. Two hours was defined for the leaching process based on other studies (Hemmati et al., 2014a; Teir et al., 2007a, 2007b; Van Essendelft and Schobert, 2009).

Two products were obtained after each leaching experimental test (T): a precipitate or solid residue (R) and a leachate solution (L). The precipitate was separated from the liquid through vacuum filtration. Following each experiment, the residues (R) were dried during $2 \mathrm{~h}$ at approximately $105{ }^{\circ} \mathrm{C}$. These residues were then characterized by XRD, XRF, and TG/DTG analysis. Leachate solutions (L) were analyzed by ICP-OES to obtain $\mathrm{Mg}$, Fe, and Si concentrations as well as to calculate their extraction percentage. $\mathrm{Mg}$, Fe, and Si extraction in the leachate solution (L) was calculated based on "in nature" contents within S-GO, as presented in the following equations:

$$
\begin{aligned}
& X_{M g}=\frac{V_{S O L} \times C_{M g}}{M_{S-G O} \times M g \%_{S-G O}} \\
& X_{F e}=\frac{V_{S O L} \times C_{F e}}{M_{S-G O} \times F e \%_{S-G O}} \\
& X_{S i}=\frac{V_{S O L} \times C_{S i}}{M_{S-G O} \times S i \%_{S-G O}}
\end{aligned}
$$

In which: $X$ represents the element mass fraction, $\mathrm{Mg} \%, \mathrm{Fe} \%$, and $\mathrm{Si} \%$ are the initial element contents in the S-GO sample, $\mathrm{M}_{\mathrm{S}-\mathrm{GO}}$ is the initial S-GO mass used in the experiments, and $\mathrm{V}_{\mathrm{SOL}}$ is the leachate solution volume after $2 \mathrm{~h}$ of reaction. $\mathrm{C}_{\mathrm{Mg}}, \mathrm{C}_{\mathrm{Fe}}$, and $\mathrm{C}_{\mathrm{Si}}$ are the concentrations of elements in the leachate solution.

\subsection{Design of experiments (DoE)}

Parameters that affect material properties can be duly evaluated with appropriate experimental planning, while the number of experiments are significantly reduced, saving time and resources. Taguchi experimental design is a broadly employed method applied to organize parameters for a specific problem, with employment of a minimum number of test series (Mangindaan et al., 2015; Yuan et al., 2015).

Table 2 shows parameters and their respective levels applied on leaching. Three levels were considered for each parameter, in which: 1 - low level, 2 - intermediate level, and 3 - high level. Values and levels for each parameter are determined from previous literature researches (Daval et al., 2013; Sanna et al., 2012; Teir et al., 2007b). Table 2 shows statistical combinations for parameters and codified levels, suggested by the Taguchi method, as well as reaction conditions for each experiment based on statistical combinations. The following parameters were identified: S-GO granulometry $(\phi)$, leaching agent concentration $\left(\mathrm{C}_{\mathrm{HCl}}\right)$, and leaching temperature $(\mathrm{T})$.

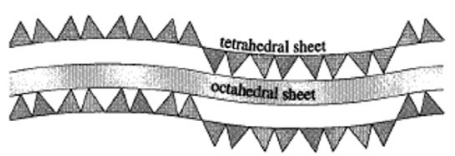

(a)

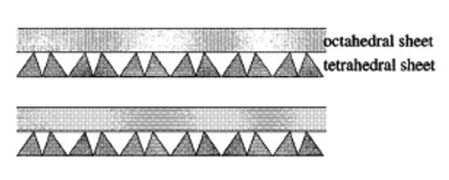

(b)

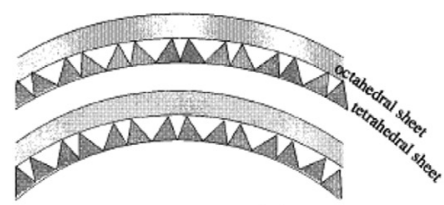

(c)

Fig. 1. Serpentine polymorphisms. a) antigorites b) lizardites c) chrysotiles (Putnis, 2003). 
Table 2

$\mathrm{L}_{9}$ orthogonal array of the Taguchi Method applied to this study.

\begin{tabular}{|c|c|c|c|c|c|c|}
\hline \multirow[t]{2}{*}{ Test } & \multicolumn{3}{|c|}{ Codified parameters } & \multicolumn{3}{|c|}{ Reaction conditions } \\
\hline & A & B & C & $\phi[\mu \mathrm{m}]$ & $\mathrm{C}_{\mathrm{HC}}[\mathrm{M}]$ & $\mathrm{T}\left[{ }^{\circ} \mathrm{C}\right]$ \\
\hline $\mathrm{T} 1$ & 1 & 1 & 1 & 75 & 1 & 25 \\
\hline $\mathrm{T} 2$ & 1 & 2 & 2 & 75 & 2 & 50 \\
\hline T3 & 1 & 3 & 3 & 75 & 4 & 100 \\
\hline $\mathrm{T} 4$ & 2 & 1 & 2 & 150 & 1 & 50 \\
\hline T5 & 2 & 2 & 3 & 150 & 2 & 100 \\
\hline T6 & 2 & 3 & 1 & 150 & 4 & 25 \\
\hline $\mathrm{T} 7$ & 3 & 1 & 3 & 300 & 1 & 100 \\
\hline T8 & 3 & 2 & 1 & 300 & 2 & 25 \\
\hline T9 & 3 & 3 & 2 & 300 & 4 & 50 \\
\hline
\end{tabular}

Thus, T1, T4, and T7 experimental tests employed a stoichiometric condition. T2, T3, T5, T6, T8, and T9 experimental tests had a non-stoichiometric condition using $2 \mathrm{M}$ and $4 \mathrm{M} \mathrm{HCl}$ concentration, which were equivalent to twice and four times excess $\mathrm{HCl}$, respectively. Mass/volume ratio fixed for all experiments and amount of S-GO mass were calculated considering the following reactions:

$$
\begin{aligned}
& \mathrm{MgO}+2 \mathrm{HCl} \rightarrow \mathrm{MgCl}_{2}+\mathrm{H}_{2} \mathrm{O} \\
& \mathrm{CaO}+2 \mathrm{HCl} \rightarrow \mathrm{CaCl}_{2}+\mathrm{H}_{2} \mathrm{O} \\
& \mathrm{F}_{3} \mathrm{O}_{4}+8 \mathrm{HCl} \rightarrow \mathrm{FeCl}_{2}+3 \mathrm{FeCl}_{3}+4 \mathrm{H}_{2} \mathrm{O} \\
& \mathrm{Al}_{2} \mathrm{O}_{3}+6 \mathrm{HCl} \rightarrow 2 \mathrm{AlCl}_{3}+3 \mathrm{H}_{2} \mathrm{O} \\
& \mathrm{Cr}_{2} \mathrm{O}_{3}+6 \mathrm{HCl} \rightarrow 2 \mathrm{CrCl}_{3}+3 \mathrm{H}_{2} \mathrm{O} \\
& \mathrm{MnO}+2 \mathrm{HCl} \rightarrow \mathrm{MnCl}_{2}+\mathrm{H}_{2} \mathrm{O}
\end{aligned}
$$

\subsection{Physicochemical characterizations}

XRD analysis was employed to identify the mineralogical composition of the solids (S-GO, SS, and R), using a Bruckers Instrument diffractometer. A range between 5 and $90^{\circ}$ was considered, on a 2 theta angle, with a copper stationary tube (CuK $\alpha 1.2$; $\lambda=1.5418$ ), operating at $40 \mathrm{kV}, 25 \mathrm{~mA}$, and a 0.015 tread size. Later on, the diffractogram obtained for S-GO was refined using the Rietveld technique in order to quantify the mineral phases. Refining of XRD peaks was accomplished with the Fullprof Suite software program.

Sequential fluorescence with wavelength dispersion (XRF) was employed for S-GO quantitative analyses of chemical composition and residues ( $\mathrm{R}$ ). It was carried out using a PANalytical Axios MAXAdvanced model device with $4.0 \mathrm{~kW}$ operating power and $60 \mathrm{kV}$ agitation. This device performed quantitative elemental chemical analyses of boron (B) to uranium (U).

For more accurate content measurements of minor elements, such as: $\mathrm{Ca}, \mathrm{Na}, \mathrm{K}, \mathrm{Al}, \mathrm{Ti}, \mathrm{Mn}, \mathrm{Cr}, \mathrm{Co}$ and $\mathrm{Cu}$, inductively coupled plasma optical emission spectroscopy (ICP-OES) was employed. Such analyses were conducted with an Arcos Spectro model equipment. A S-GO powder sample mass of $250 \pm 10 \mathrm{mg}$ was taken. ICP-OES analyses were also done to measure $\mathrm{Mg}$, Fe, and Si contents in the leachate solution (L) for all experimental tests.

SEM-EDS analysis was conducted to determine S-GO morphology and elemental distribution. A Zeiss EVO LS 15 equipped with an EDS/EBDS Oxford INCA Energy 250 system (Oxford Instruments, Abingdon, Oxfordshire, UK) was used for the scanning electron microscope analysis to conduct a dispersive energy microanalysis. It operated between 0.2 and $30 \mathrm{kV}$ and employed an
Everhart-Thornley secondary electron detector, $8.5 \mathrm{~mm}$ away from the sample.

Thermogravimetric analysis coupled with mass spectrometry (TG-MS) was employed to analyze and identify thermal decomposition behavior of different S-GO mineral phases, as well as composition of gases released. Such analysis was performed in one SETARAM 92-16,18 thermobalance coupled with a mass spectrometer from MKS Instruments, e-vision ${ }^{+}$model. A $68 \mathrm{mg}$ sample was used and placed inside an alumina crucible. Argon 5.0 (Ar) with a $32 \mathrm{~mL} / \mathrm{min}$ was employed as purging gas. A $25-1000{ }^{\circ} \mathrm{C}$ temperature range was considered, at a $3{ }^{\circ} \mathrm{C} / \mathrm{min}$ heating rate.

Thermogravimetric analyses (TGA) were carried out to assess thermal behavior for S-GO, SS, and residues (R). These TGAs were carried out in a TA Instrument SDT-TGA-DSC Q600 simultaneous system. A $30 \pm 2 \mathrm{mg}$ sample mass in a $5 \times 5 \mathrm{~mm}$ alumina crucible was used for all tests, with a dynamic nitrogen atmosphere $\left(\mathrm{N}_{2}\right)$ used as a purge gas, at a flow rate of $100 \mathrm{~mL} / \mathrm{min}$, and $10^{\circ} \mathrm{C} / \mathrm{min}$ heating rate. Temperatures were set between 30 and $1000{ }^{\circ} \mathrm{C}$.

\section{Results and discussion}

\subsection{S-GO physicochemical characterization}

Fig. 2 and Table 3 present an X-ray diffractogram and reference codes for mineral phases within S-GO. As it can be observed, S-GO is a serpentinite rock, which has a heterogeneous composition, with lizardite $1 \mathrm{~T}$ as the main mineral phase. In addition, clinochrysotile, brucite, and magnetite were present. The Rietveld technique indicates that S-GO exhibits $90.67 \%$ serpentines, $6.27 \%$ brucite, $1.96 \%$ magnetite and, 1.09\% magnesite.

$\mathrm{S}-\mathrm{GO}$ is a mixture between brucite and serpentines, which is the result of a dunite serpentinization process (olivines) with low silica activity $\left(a \mathrm{SiO}_{2}\right)$ and high water activity $\left(a \mathrm{H}_{2} \mathrm{O}\right)$ (Evans, 2008; Frost and Beard, 2007; Hostetler et al., 1966). Several authors reported this mixture worldwide in the presence of carbonates and/or magnetites, such as Alaska, Switzerland, Canada, South Africa, and Japan, among others (Assima et al., 2014; Harrison et al., 2013; Hostetler et al., 1966). According to Hostetler et al. (1966), Si free brucite (or native brucite) present in serpentinite rocks is found in variable amounts. However, brucite molar fractions never exceeds those of serpentines.

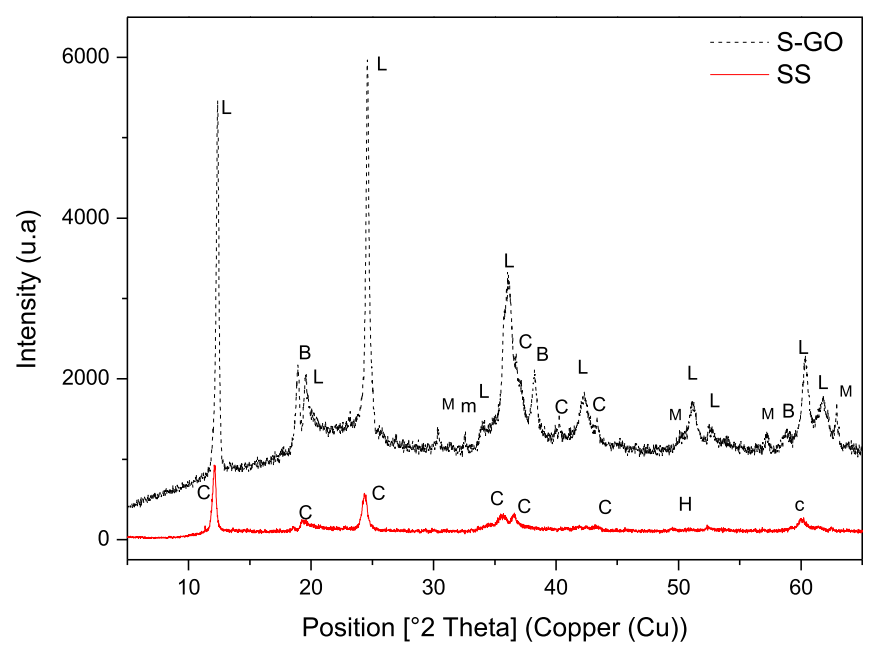

Fig. 2. XRD diffractograms with the list of mineral phase peaks detected from S-GO and SS. In which, L: Lizardite 1T, B: Brucite, m: magnesite, M: Magnetite, H: Hematite and C: Clinochrysotile. 
Table 3

Composition of S-GO mineral phases based on XRD results.

\begin{tabular}{llll}
\hline Material & Ref. code & Mineral name & Compound name \\
\hline S-GO & $00-050-1625$ & Trigonal Lizardite 1T & Aluminum iron magnesium silicate \\
& $00-027-1275$ & Clinochrysotile & Magnesium silicate hydroxide \\
& $01-083-0114$ & Brucite & Magnetite \\
& $01-075-1609$ & Magnetite & Magnesium carbonate \\
\hline
\end{tabular}

A summary with XRF results and ICP-OES analyses is shown on Table 4. Oxides from S-GO were determined by XRF and elemental composition by ICP-OES. These results show that S-GO contains 43.33\% $\mathrm{MgO}, 40.64 \% \mathrm{SiO}_{2}$, and $12.61 \% \mathrm{Fe}_{2} \mathrm{O}_{3 \mathrm{t}}$. Others metals were also detected, such as: $\mathrm{K}, \mathrm{Na}, \mathrm{Al}, \mathrm{Ti}, \mathrm{Mn}$, and $\mathrm{Cr}$ in less than $2.4 \%$ of solid. The high concentration of $\mathrm{Fe}_{2} \mathrm{O}_{3 \mathrm{t}}$ indicates that the weathered serpentinite has been residually enriched during weathering (Oskierski et al., 2013).

S-GO morphology and elemental distribution are presented on Figs. 3 and 4, respectively. Elemental distribution allows the identification and visualization of element arrangement on S-GO surface. According to Fig. 3, S-GO has an irregular morphology, with overlapping layers from different structures. In order to better observe structures of lizardite 1T (LIZ) and clinochrysotile (CHR), enlargements of 5000 times $(1-2 \mu \mathrm{m})$ were done in specific zones of a S-GO sample. It was observed that layer overlapping is related to flat and cylindrical structures of lizardite 1T and clinochrysotile, respectively. Fig. 4 shows the elemental distribution for magnesium $(\mathrm{Mg})$, silicon $(\mathrm{Si})$, aluminum $(\mathrm{Al})$, and total iron $\left(\mathrm{Fe}_{\mathrm{t}}\right)$. It was possible to determine from Fig. $4 \mathrm{a}$ and $4 \mathrm{~b}$ that $\mathrm{Mg}$ and Si are uniformly distributed on S-GO. However, Fig. $4 \mathrm{c}$ and $4 \mathrm{~d}$ show that $\mathrm{Al}$ and $\mathrm{Fe}_{\mathrm{t}}$ are distributed in specific regions at low concentrations.

When Figs. 3 and 4c are compared, it is verified that $\mathrm{Al}$ is jointly located in regions where lizardite $1 \mathrm{~T}$ is distributed. The existing relation between $\mathrm{Al}$ and lizardites is due to a higher affinity for trivalent elements $\left(\mathrm{Al}^{3+}\right.$ and $\mathrm{Fe}^{3+}$ ), which replace $\mathrm{Si}^{4+}$ from the tetrahedral sheet $(\mathrm{T})$ in the lizardite structure, when compared to chrysotile (Wicks and Whittaker, 1975). In addition, $\mathrm{Al}^{3+}$ only replaces $\mathrm{Mg}^{2+}$ in external layers of chrysotile fibers, in a very limited manner, due to the necessary maladjustment to produce fiber curvatures (Wicks and Whittaker, 1975).

When $\mathrm{Fe}_{\mathrm{t}}$ distribution is observed (Fig. 4d), high concentrations in specific zones can be verified, due to the presence of magnetite. Furthermore, part of the $\mathrm{Fe}_{t}$ presents a different elemental distribution when compared to $\mathrm{Mg}, \mathrm{Si}$, and $\mathrm{Al}$ (as shown in the yellow circle), denoting that $\mathrm{Mg}, \mathrm{Si}$, and $\mathrm{Al}$ are not linked to $\mathrm{Fe}_{\mathrm{t}}$ in this region.

Table 4

S-GO chemical and elemental composition.

\begin{tabular}{lllll}
\hline XRF & & & ICP & \\
\cline { 1 - 2 } Oxides & Concentration (\%) & & Elements & Concentration (\%) \\
\hline $\mathrm{SiO}_{2}{ }^{\mathrm{b}}$ & 40.64 & $\mathrm{Si}^{\mathrm{b}}$ & 8.40 \\
$\mathrm{MgO}^{\mathrm{b}}$ & 43.33 & $\mathrm{Mg}^{\mathrm{b}}$ & 23.01 \\
$\mathrm{CaO}$ & 0.10 & $\mathrm{Ca}$ & $279.5^{\mathrm{a}}$ \\
$\mathrm{Fe}_{2} \mathrm{O}_{3 \mathrm{t}} \mathrm{b}^{\mathrm{b}}$ & 12.61 & $\mathrm{Fe}$ & 4.49 \\
$\mathrm{~K}_{2} \mathrm{O}$ & n.d. & $\mathrm{K}$ & $<0.01^{\mathrm{a}}$ \\
$\mathrm{Na}_{2} \mathrm{O}$ & n.d. & $\mathrm{Na}$ & $<0.02^{\mathrm{a}}$ \\
$\mathrm{Al}_{2} \mathrm{O}_{3}$ & 1.17 & $\mathrm{Al}$ & 0.35 \\
$\mathrm{TiO}_{2}$ & n.d. & & $\mathrm{Ti}$ & $140.3^{\mathrm{a}}$ \\
$\mathrm{MnO}^{\mathrm{b}}$ & 0.20 & $\mathrm{Mn}$ & n.d. \\
$\mathrm{Cr}_{2} \mathrm{O}_{3}$ & 1.02 & $\mathrm{Cr}$ & n.d. \\
\hline
\end{tabular}

n.d. $=$ not determined.

a $\mathrm{mg} / \mathrm{Kg}$.

b For calculation of $\mathrm{Mg}, \mathrm{Fe}$, and Si concentrations on leachate (L), mean values of $\mathrm{XRF}$ and ICP-OES were used.

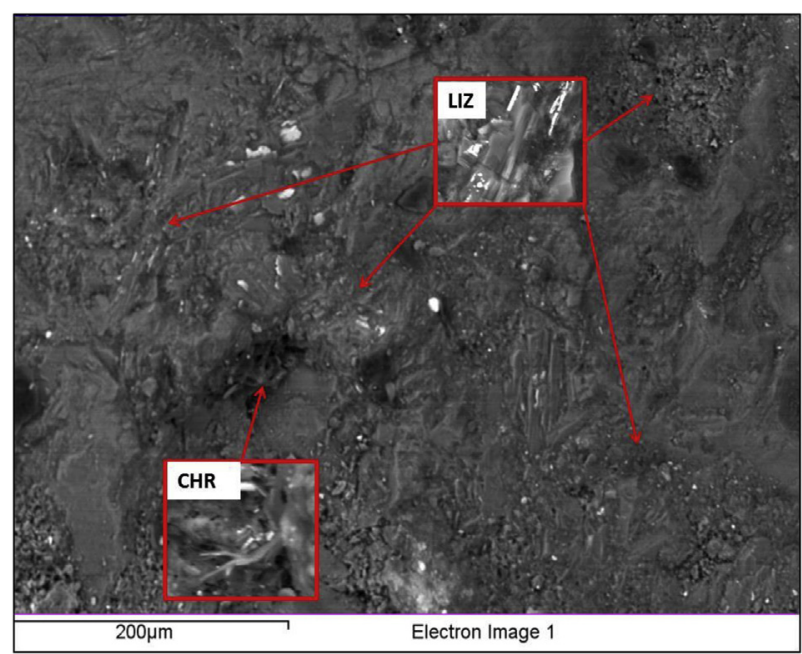

Fig. 3. S-GO micrographs in $200 \mu \mathrm{m}$.

According to Wicks and Whittaker (1975), replacement of $\mathrm{Fe}^{2+}$ by $\mathrm{Mg}^{2+}$ and $\mathrm{Si}^{4+}$ in lizardites is extremely limited due to the structural order needed to form flat layers. On the other hand, $\mathrm{Fe}^{3+}$ can replace $\mathrm{Mg}^{2+}$ and $\mathrm{Si}^{4+}$, although with higher preference by $\mathrm{Mg}^{2+}$, due to the similar atomic diameter between both cations $\left(\emptyset_{\mathrm{Fe} 3+}=0.64, \emptyset_{\mathrm{Mg} 2+}=0.72\right.$, and $\left.\emptyset_{\mathrm{Si} 4+}=0.40\right)$. It can be observed from Fig. $4 \mathrm{~d}$ that part of the $\mathrm{Fe}_{\mathrm{t}}$ is uniformly distributed in smaller concentrations over the clinochrysotile region.

\subsection{S-GO thermal behavior}

Fig. 5 shows the thermal decomposition behavior and mass spectrum for S-GO. The TG curve exhibits two mass losses, first at $200-500{ }^{\circ} \mathrm{C}$ and then at $500-800{ }^{\circ} \mathrm{C}$. Such losses were associated to thermal decomposition of several mineral phases identified through XRD diffractograms, such as brucite, magnesite, lizardite $1 \mathrm{~T}$, and clinochrysotile, respectively. Two substances were identified through mass spectrometry (MS) which are released during decomposition processes of mineral phases from S-GO: a significant $\mathrm{H}_{2} \mathrm{O}$ fraction (which is characteristic of the dehydroxilation process) and a minimum $\mathrm{CO}_{2}$ fraction (which is characteristic of the decarboxylation process). Reported total mass loss was approximately $15.3 \%$, mainly referring to hydroxyls $\left(\mathrm{OH}^{-}\right)$released as $\mathrm{H}_{2} \mathrm{O}$.

The first mass loss was related to brucite and magnesite thermal decompositions. According to the literature (Assima et al., 2013; Balucan et al., 2013), brucite dehydroxilation and magnesite decarboxylation are accomplished at temperatures below $500{ }^{\circ} \mathrm{C}$. The second mass loss was related to lizardite $1 \mathrm{~T}$ and clinochrysotile thermal decompositions, since these mineral phases only decompose at temperatures above $500{ }^{\circ} \mathrm{C}$ (Balucan et al., 2013; Földvári, 2011).

The TG-MS result indicated that thermal decomposition of brucite and magnesite simultaneously produced water vapor $\left(\mathrm{H}_{2} \mathrm{O}\right)$ 


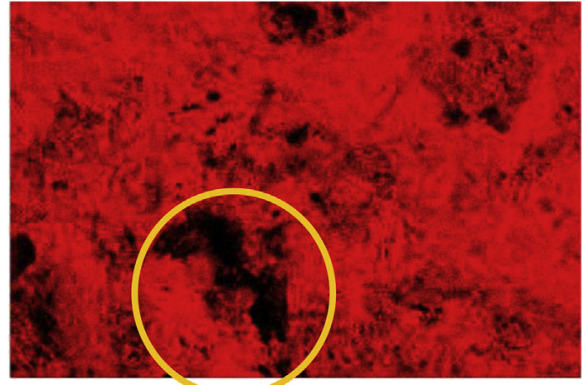

Mg Ka1_2

(a)

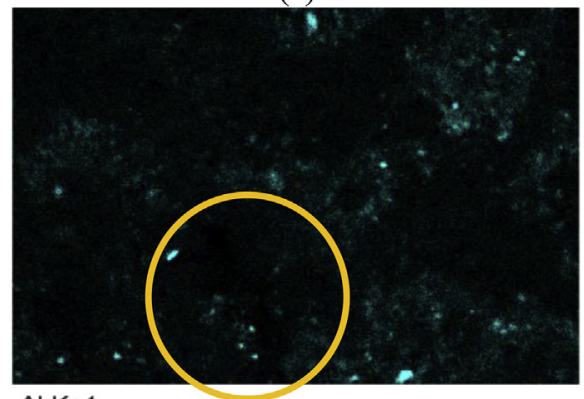

(c)

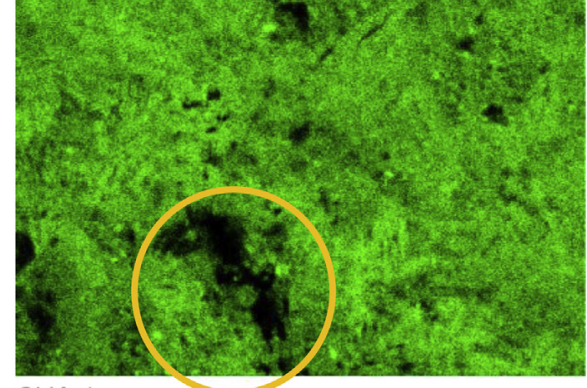

Si Ka1

(b)

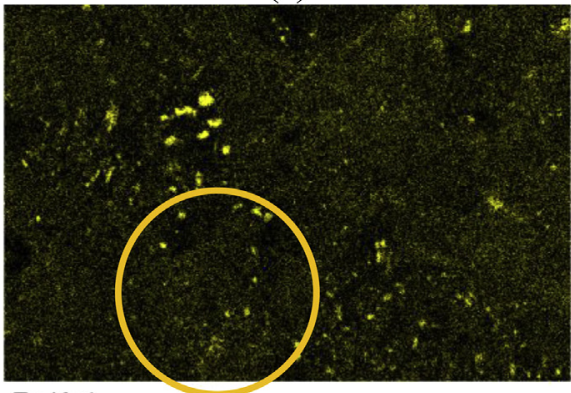

$\mathrm{Fe} \mathrm{Ka1}$

Fig. 4. Element distribution by EDS analysis. a) $\mathrm{Mg}$ b) $\mathrm{Si} \mathrm{c)} \mathrm{Al}$ and d) Fe.

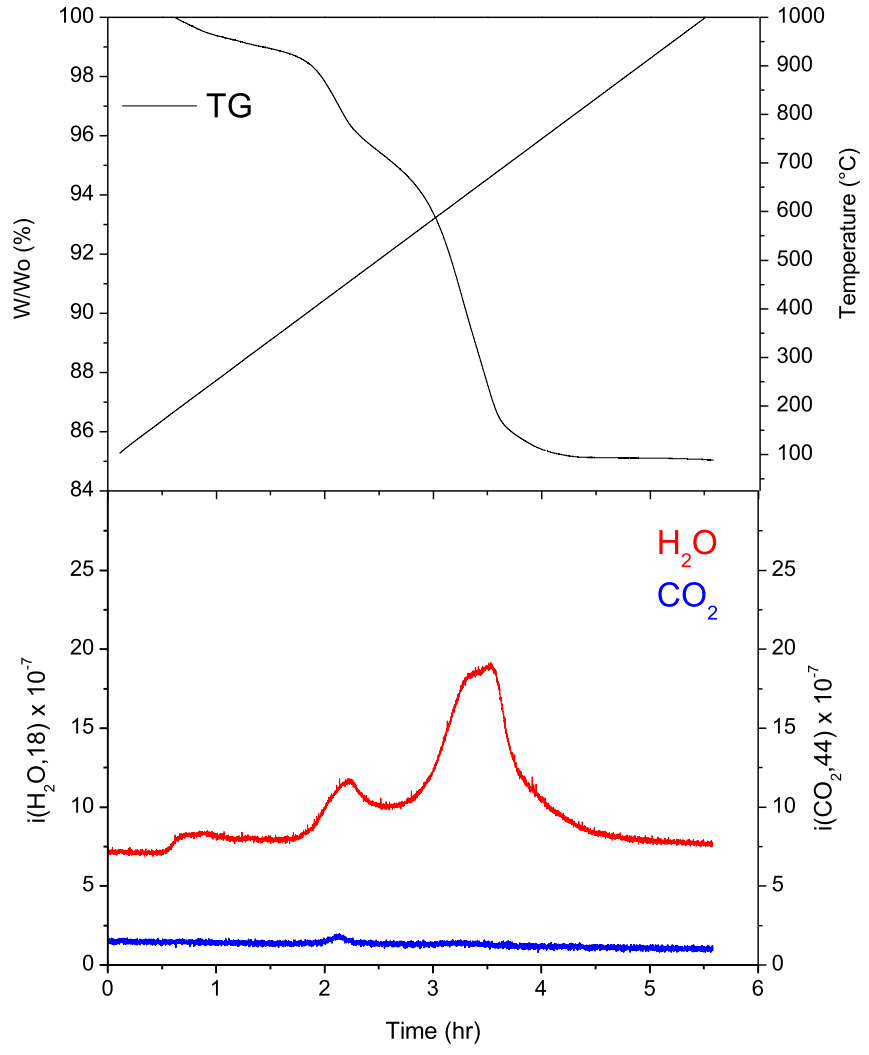

Fig. 5. TG-MS for S-GO.

and carbon dioxide $\left(\mathrm{CO}_{2}\right)$, which are associated with dehydroxilation (Eq. (10)) and decarboxylation (Eq. (11)) reactions, respectively.

$$
\begin{aligned}
& \mathrm{Mg}(\mathrm{OH})_{2(\mathrm{~s})} \rightarrow \mathrm{MgO}_{(\mathrm{s})}+\mathrm{H}_{2} \mathrm{O}_{(\mathrm{g})} \\
& \mathrm{MgCO}_{3(\mathrm{~s})} \rightarrow \mathrm{MgO}_{(\mathrm{s})}+\mathrm{CO}_{2(\mathrm{~g})}
\end{aligned}
$$

It can be observed from Fig. 5 that the region of interest begins with a stable conversion at $200{ }^{\circ} \mathrm{C}$ until maximum conversion at $400{ }^{\circ} \mathrm{C}$. Through the use of brucite and magnesite contents obtained by Rietveld, and considering the reactions above (Eq. (10) and Eq. (11)), percentages of $\mathrm{H}_{2} \mathrm{O}$ and $\mathrm{CO}_{2}$ produced were determined to be approximately $77.29 \%$ and $22.71 \%$, respectively.

With such percentages, the mass loss assigned to $\mathrm{H}_{2} \mathrm{O}$ and $\mathrm{CO}_{2}$ can be distinguished, respectively, from the total mass loss in this region $\left(200-400{ }^{\circ} \mathrm{C}\right)$. Considering both dehydroxilation (Eq. (10)) and decarboxylation (Eq. (11)) reactions, brucite and magnesite masses were determined as well as the percentages of these minerals. Results show contents equivalent to $5.93 \%$ brucite and $1.03 \%$ magnesite. Brucite content was compared to the Rietveld quantification, with an average value of approximately $6.10 \pm 0.24 \%$.

TG/DTG curves for S-GO were compared to a clinochrysotile sample (SS) in order to determine the dehydroxilation temperature of different S-GO mineral phases. The SS sample was previously analyzed by XRD. Fig. 2 presents XRD diffractograms for S-GO and SS, indicating diffraction lines for each mineral phase. It can be verified that SS presents clinochrysotile as the main mineral phase and some hematite traces.

Fig. 6 presents TG/DTG curves for S-GO and SS, respectively. Fig. 6a presents TG curves for S-GO (black line) and SS (red line). A small mass loss between the interval of $200{ }^{\circ} \mathrm{C}$ and $500{ }^{\circ} \mathrm{C}$ can be observed in the TG curve for SS, probably due to brucite traces present in the SS. Non-detection of brucite in the SS through XRD can be due to low contents of this mineral, causing low intensity of diffraction lines (Hostetler et al., 1966). However, there was a higher mass loss in the TG curve for S-GO, within the $200{ }^{\circ} \mathrm{C}-500{ }^{\circ} \mathrm{C}$ interval.

A higher mass loss in the SS TG curve is found in the $500{ }^{\circ} \mathrm{C}-800^{\circ} \mathrm{C}$ interval, referring to clinochrysotile dehydroxilation. 


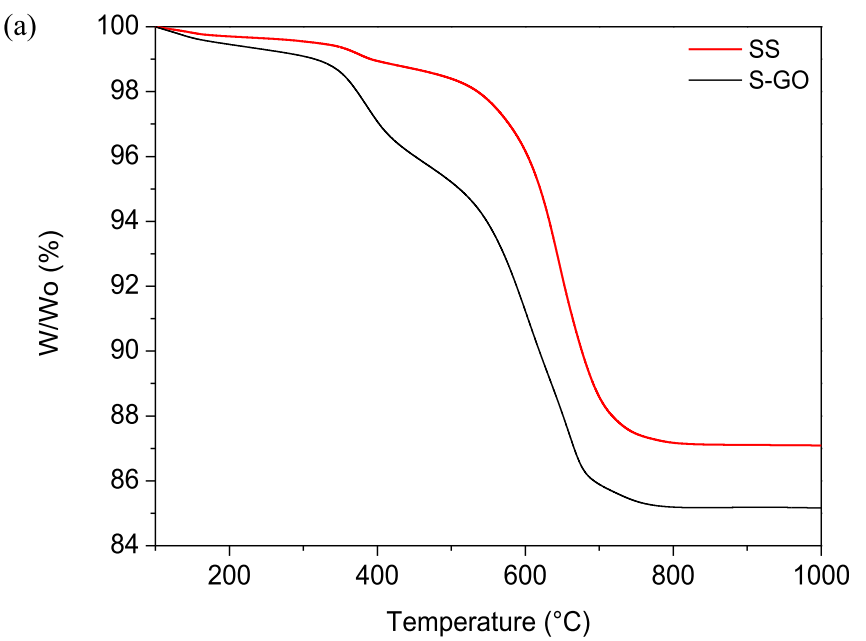

(b)

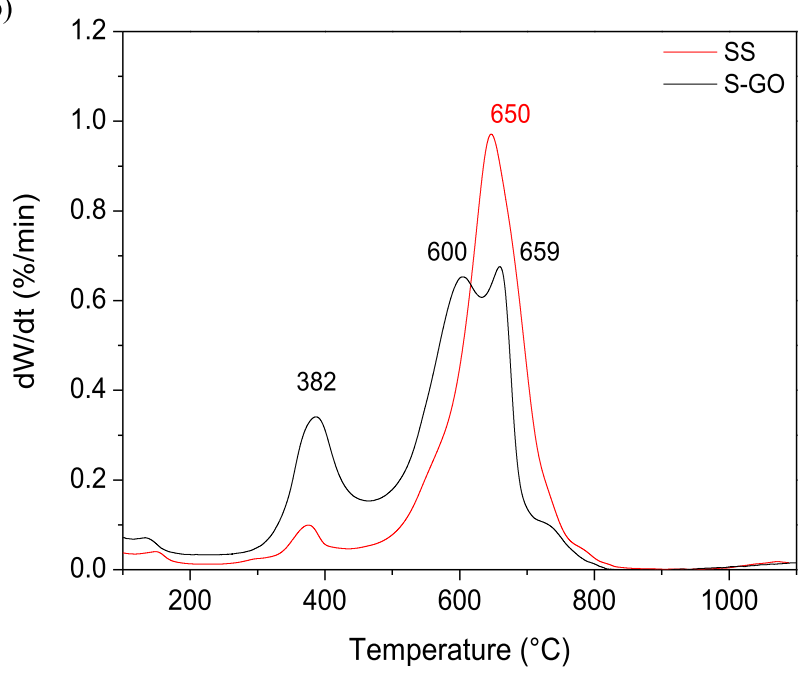

Fig. 6. TG/DTG curves for SS and S-GO.

This fact is better observed on Fig. 6b, in which the DTG curve for SS presented its highest peak at $650^{\circ} \mathrm{C}$.

According to Fig. 6a, S-GO presented its higher mass loss between $500^{\circ} \mathrm{C}$ and $800{ }^{\circ} \mathrm{C}$, referring to serpentines (lizardite $1 \mathrm{~T}$ and clinochrysotile). Two DTG peaks are verified on Fig. 6b with $600{ }^{\circ} \mathrm{C}$ and $659^{\circ} \mathrm{C}$ temperatures.

When DTG peaks for SS and S-GO are compared, the maximum DTG peak for SS $\left(650{ }^{\circ} \mathrm{C}\right)$ happens before the DTG peak for S-GO $\left(659{ }^{\circ} \mathrm{C}\right)$. The difference between temperatures is due to the structure of clinochrysotile fibers. The fiber from the SS was more exposed and free to perform the dehydroxilation process when compared to S-GO fiber. This demonstrates that the $659{ }^{\circ} \mathrm{C}$ temperature refers to dehydroxilation of the clinochrysotile present in the S-GO.

Thus, thermal behavior analyses performed to S-GO demonstrated dehydroxilation temperatures for brucite, lizardite $1 \mathrm{~T}$, and clinochrysotile, equivalent to $382{ }^{\circ} \mathrm{C}, 600{ }^{\circ} \mathrm{C}$, and $659{ }^{\circ} \mathrm{C}$, respectively. The temperature result due to serpentine dehydroxilation for S-GO (lizardite 1T and clinochrysotile) seemed to be inconsistent with the result reported by Dlugogorski and Balucan (2014) and Viti (2010). Such divergence is associated to different $\mathrm{Al}_{2} \mathrm{O}_{3}$ contents between both lizardites $1 \mathrm{~T}$. In this study, the S-GO lizardite $1 \mathrm{~T}$ presents a content of $1.17 \%$. On the other hand, the lizardite $1 \mathrm{~T}$ employed by Viti (2010) presented a content of $2.89 \%$, being more stable thermally.
Basta and Kader (1969) extensively evaluated the thermal stability for several lizardites with low $\mathrm{Al}^{3+}$ contents, in the form of $\mathrm{Al}_{2} \mathrm{O}_{3}$ (0.28-1.00\%), as well as Weber and Greer (1965) and Földvári (2011). These authors reported a dehydroxilation temperature in the interval of $635{ }^{\circ} \mathrm{C}-685^{\circ} \mathrm{C}$. However, thermal stability of lizardite with high $\mathrm{Al}_{2} \mathrm{O}_{3}$ contents $(2.39-2.89 \%)$, studied by Viti (2010), presented a dehydroxilation temperature in the range of $708^{\circ} \mathrm{C}-714^{\circ} \mathrm{C}$, demonstrating an influence of $\mathrm{Al}^{3+}$ in the thermal stability of lizardite $1 \mathrm{~T}$.

\subsection{Leaching experiments}

Leachate solutions (L) were observed to be yellow and the solid residue ( $R$ ) was slightly gray. Color intensities were in accordance with reaction conditions established on Table 2 . It is worth mentioning that experimental tests which used $25{ }^{\circ} \mathrm{C}$ temperature presented an exothermic behavior, so that the temperature increased by approximately $20^{\circ} \mathrm{C}$, reaching $45-55^{\circ} \mathrm{C}$ in the first $10 \mathrm{~min}$ of reaction. Extractions achieved in the leachate (L) for $\mathrm{Mg}$, Fe, and Si are shown on Table 5.

As it was verified, maximum $\mathrm{Mg}$ and Fe extractions were obtained in T3 (97\% and 100\% for Mg and Fe extractions, respectively). Nonetheless, all experiments that used $100{ }^{\circ} \mathrm{C}$ temperatures obtained the highest $\mathrm{Mg}$ and $\mathrm{Fe}$ extractions, of approximately $95.5 \pm 1.5 \%$ and $96.3 \pm 4.5 \%$, respectively.

Although all experiments obtained low Si extractions (1-4\%), tests T3, T6, and T9, which employed a $4 \mathrm{M} \mathrm{HCl}$ concentration, reported the lowest Si extraction. Such singularity is due to the collapse process produced at low $\mathrm{pH}$, in which transformation of serpentines to form amorphous silica $\left(\mathrm{SiO}_{2}\right)$ is fast and direct (Oskierski et al., 2013; Park and Fan, 2004). The collapse process was observed for chrysotiles, where external fiber sheets of octahedral $\mathrm{Mg}^{2+}(\mathrm{O})$ react in a fast manner, leaving the tetrahedral $\mathrm{Si}^{4+}$ ( $\mathrm{T}$ ) sheet intact to form siloxanes $(\mathrm{Si}-\mathrm{O}-\mathrm{Si})$. These have a highly porous infrastructure with encapsulated silica and it is poor in $\mathrm{Mg}$, which collapses quickly to form amorphous silica (McCutcheon et al., 2015; Yu and Wang, 2011).

On the other hand, experiments conducted at a temperature of $25^{\circ} \mathrm{C}$ obtained the lowest $\mathrm{Mg}$ and Fe extractions in stoichiometric (T1) and non-stoichiometric conditions (T6 and T8). Nonstoichiometric tests (T6 and T8) exhibited more Fe extraction than $\mathrm{Mg}$ extraction. This behavior was also verified with less intensity when experiments were conducted at $50^{\circ} \mathrm{C}$ and $100^{\circ} \mathrm{C}(\mathrm{T} 2$, T3, T5, and T9).

In order to assess if this behavior is a characteristic from S-GO or if it is due to excess acid, experiments under stoichiometric conditions were also performed for tests T2, T3, T5, T6, T8, and T9. In order to accomplish this, mass/volume ratios were employed, equivalent to 73 and $146 \mathrm{~g} / \mathrm{L}$ for $2 \mathrm{M}$ and $4 \mathrm{M}$ acid concentrations,

Table 5

$\mathrm{Mg}, \mathrm{Fe}$, and Si extracted from S-GO, for all experimental tests.

\begin{tabular}{llllllll}
\hline Test & \multicolumn{2}{l}{ Reaction conditions } & \multicolumn{3}{l}{$\begin{array}{l}\text { Extraction of metals on } \\
\text { leached solutions }(\mathrm{L})\end{array}$} \\
\cline { 2 - 3 } \cline { 6 - 7 } & $\phi(\mu \mathrm{m})$ & $\mathrm{C}_{\mathrm{HCl}}[\mathrm{M}]$ & $\mathrm{T}\left({ }^{\circ} \mathrm{C}\right)$ & & $\mathrm{Mg} \%$ & $\mathrm{Fe} \%$ & $\mathrm{Si} \%$ \\
\hline $\mathrm{T} 1$ & 75 & 1 & 25 & & 36 & 33 & 3 \\
$\mathrm{~T} 2$ & 75 & 2 & 50 & & 76 & 78 & 2 \\
T3 & $\mathbf{7 5}$ & $\mathbf{4}$ & $\mathbf{1 0 0}$ & $\mathbf{9 7}$ & $\mathbf{1 0 0}$ & $\mathbf{1}$ \\
$\mathrm{T} 4$ & 150 & 1 & 50 & & 61 & 58 & 4 \\
T5 & $\mathbf{1 5 0}$ & $\mathbf{2}$ & $\mathbf{1 0 0}$ & $\mathbf{9 4}$ & $\mathbf{9 8}$ & $\mathbf{2}$ \\
$\mathrm{T} 6$ & $\mathbf{1 5 0}$ & 4 & 25 & & 40 & 58 & 1 \\
T7 & $\mathbf{3 0 0}$ & $\mathbf{1}$ & $\mathbf{1 0 0}$ & $\mathbf{9 7}$ & $\mathbf{9 1}$ & $\mathbf{4}$ \\
$\mathrm{T} 8$ & 300 & 2 & 25 & & 35 & 42 & 2 \\
$\mathrm{~T} 9$ & 300 & 4 & 50 & 79 & 86 & 1 \\
\hline
\end{tabular}


respectively. Results are presented on Table 6.

As observed on Table 6, Mg and Fe extractions remained similar when compared with non-stoichiometric tests on Table 5, indicating that excess acid for S-GO did not have a significant effect. Thus, 2 and 4 times $\mathrm{HCl}$ excess improved the efficiency for $\mathrm{Mg}$ and Fe extraction by only $3-10 \%$. This is important since an increase of mass/volume proportion can greatly reduce the capital and operational cost, due to the smaller number of reactors required for the process (Sanna et al., 2013).

Studies by Daval et al. (2013) and Sanna et al. (2013) have employed lizardite. The authors obtained a Mg extraction between 5 and 70\%; Fe extraction was smaller than Mg extraction, even when excess acid was used in the leaching process. Such difference in $\mathrm{Mg}$ and Fe extractions can be explained due to the mineralogy of the material, since the used serpentines presented hematite contents, sometimes mixed with calcite and almost never mixed with native brucite.

As verified, when $\mathrm{Mg}$ and Fe extractions from T3 were compared to other studies that employed lizardite, the leaching process from this study was more efficient. Moreover, contrary to studies mentioned previously, $\mathrm{Mg}$ and Fe extractions were very similar, and Fe extraction was more efficient than $\mathrm{Mg}$ extraction in some cases. On the other hand, Alves et al. (2013) and Teir et al. (2007a) reported smaller $\mathrm{Mg}$ and $\mathrm{Fe}$ extractions when large size particles were used.

This study verified that experiments performed at a temperature of $100{ }^{\circ} \mathrm{C}$, with an excess of acid, as well as small sized particles, seemed to not have influenced the performance for $\mathrm{Mg}$ and $\mathrm{Fe}$ extraction.

This behavior was associated to the presence of other simpler minerals free of $\mathrm{Si}$, such as native brucite, and high content of iron within the S-GO. Since brucite is found with lizardite 1T inside the S-GO structure, there is a possibility of brucite to contain Fe in its structure, as iron hydroxide (Hostetler et al., 1966; Lima, 1997). Thus, when leaching is done at low concentration and temperature (T1), the native brucite quickly reacts, releasing Mg and Fe. According Baumeister (2012) the kinetics of dissolution is effect of iron oxidation and cations substitution, so, mineral dissolution on weathering appears to follow a specific order: pyroxene $>$ Fe rich serpentine $>\mathrm{Mg}$ rich serpentine $>\mathrm{Al}$ rich serpentine.

Native brucite (rich in $\mathrm{Fe}$ ) from $\mathrm{S}-\mathrm{GO}$ is found between serpentine layers as fine particles dispersed throughout the rock (Hostetler et al., 1966). Due to the high native brucite reactivity, it dissolves quickly, increasing the reaction surface. After brucite dissolution, the acid reacts with iron rich serpentines during the leaching process. These material properties do not affect $\mathrm{Mg}$ and $\mathrm{Fe}$ extraction which use $300 \mu \mathrm{m}$ granulometries. In addition, the $\mathrm{Al}^{3+}$ content in the lizardite 1T structure did not have a significant effect regarding S-GO structural stability, allowing dissolution of a great amount of serpentines at $100{ }^{\circ} \mathrm{C}$.

Table 6

$\mathrm{Mg}, \mathrm{Fe}$, and Si extracted from S-GO under stoichiometric conditions.

\begin{tabular}{llllllll}
\hline \multirow{2}{*}{ Test } & \multicolumn{2}{l}{ Reaction conditions } & & \multicolumn{3}{l}{$\begin{array}{l}\text { Extraction of metals on } \\
\text { leached solutions }(\mathrm{L})\end{array}$} \\
\cline { 2 - 3 } \cline { 7 - 8 } & $\phi(\mu \mathrm{m})$ & $\mathrm{C}_{\mathrm{HCl}}[\mathrm{M}]$ & $\mathrm{T}\left({ }^{\circ} \mathrm{C}\right)$ & & $\mathrm{Mg} \%$ & $\mathrm{Fe} \%$ & $\mathrm{Si} \%$ \\
\hline T2E & 75 & 2 & 50 & & 62 & 63 & 2 \\
T3E & $\mathbf{7 5}$ & $\mathbf{4}$ & $\mathbf{1 0 0}$ & $\mathbf{9 4}$ & $\mathbf{9 7}$ & $\mathbf{0}$ \\
T5E & $\mathbf{1 5 0}$ & $\mathbf{2}$ & $\mathbf{1 0 0}$ & $\mathbf{9 6}$ & $\mathbf{9 3}$ & $\mathbf{2}$ \\
T6E & 150 & 4 & 25 & & 38 & 50 & 1 \\
T8E & 300 & 2 & 25 & & 32 & 37 & 1 \\
T9E & 300 & 4 & 50 & 67 & 77 & 0 \\
\hline
\end{tabular}

Bold indicates high Mg extraction.

\subsection{Relationship between mineral structure and leaching performance}

During the S-GO leaching process, the mineral phases show different behaviors that depend on their physical, chemical, and textural properties, as well as mineralogical composition and process parameters.

In order to understand the mechanisms involved in S-GO leaching, as well as comprehend the relationship between mineral structure and leaching performance, TGA and XRD analyses were performed in the residues (R). A comparison between TG/DTG curves was done for $\mathrm{S}-\mathrm{GO}$ and residues $(\mathrm{R})$, identifying partial or total reaction for each mineral phase contained in the S-GO after leaching.

Fig. 7 shows TG curves for all residues. It was observed that residues from tests that employed a $100{ }^{\circ} \mathrm{C}$ temperature (R3, R5, and R7) presented smaller mass losses. However, residues from tests that employed a $25{ }^{\circ} \mathrm{C}$ temperature presented the highest mass losses (R1, R6, and R8). This difference indicated that tests performed at $25{ }^{\circ} \mathrm{C}$ still present hydroxyl groups $\left(\mathrm{OH}^{-}\right)$, which are characteristic from brucite or serpentines that cannot react with the acid and are still part of the residues.

In order to examine the mineral phase that is still present in the residue (R), DTG curves and diffractograms are shown on Figs. 8 and 9, respectively. Fig. 8 shows that the DTG curve for S-GO (dotted black line) follows all residues ( $R$ ) (black line), which allows the observation of differences among DTG peaks. Large differences were verified for all residues ( $R$ ).

It can be observed that characteristic DTG peaks from brucite decomposition $\left(382^{\circ} \mathrm{C}\right)$ were eliminated from DTG curves in those residues obtained at a $25{ }^{\circ} \mathrm{C}$ temperature (R1, R6, and $\mathrm{R} 8$ ). In addition, characteristic peaks from clinochrysotile decomposition $\left(659^{\circ} \mathrm{C}\right)$ were less intense; however, peaks referring to lizardite $1 \mathrm{~T}$ decomposition $\left(600^{\circ} \mathrm{C}\right)$ were not modified and were more intense.

Diffraction lines referring to brucite and clinochrysotile were not visualized in diffractograms for residues R1, R6, and R8 (Fig. 9). This fact can be verified by the intensity of diffraction lines signalized with a blue cross $(\mathrm{X})$ between diffractograms for S-GO (dotted red line) and residues R1, R6, and R8 (black line); corroborating DTG curves.

Based on DTG curves and diffractograms, it can be verified that although T1, T6, and T8 tests had the lowest Mg and Fe extractions (between $35-40 \%$ and $33-58 \%$, respectively, Table 5), this extraction corresponded to $\mathrm{Mg}$ and Fe contained in brucite and part of

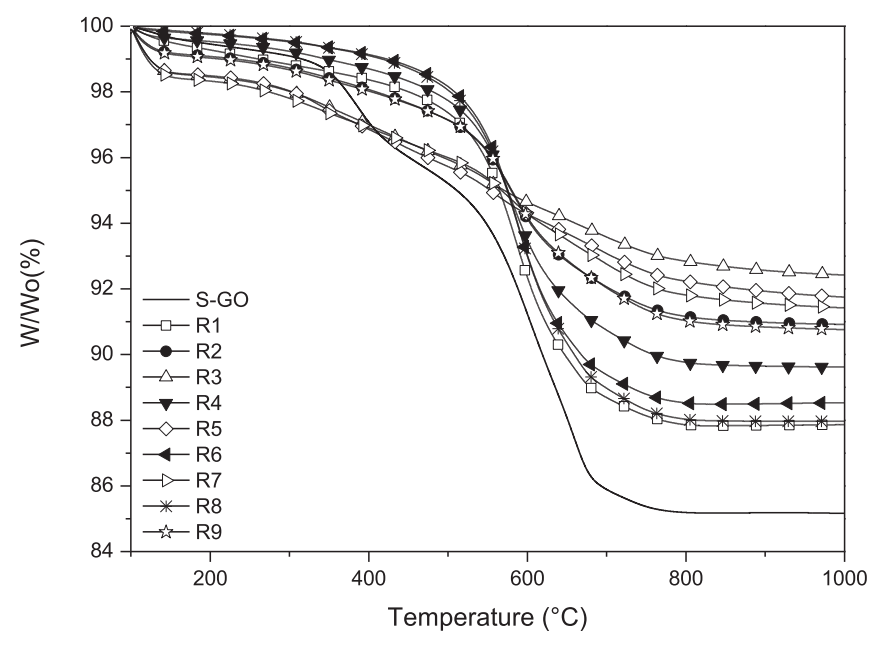

Fig. 7. TG curves for S-GO and residues (R), for all experimental tests. 


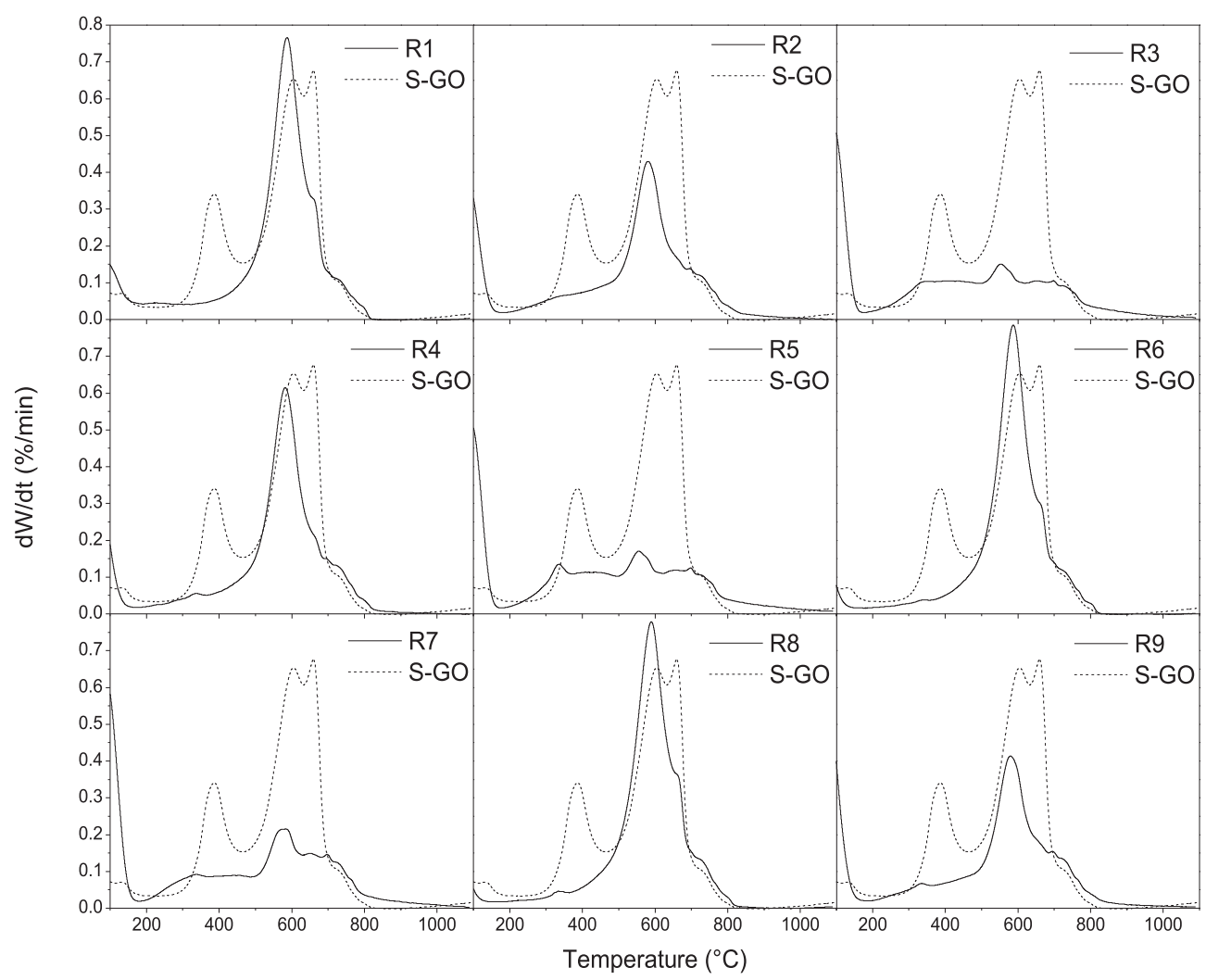

Fig. 8. DTG curves for S-GO and residues (R), for all experimental tests.

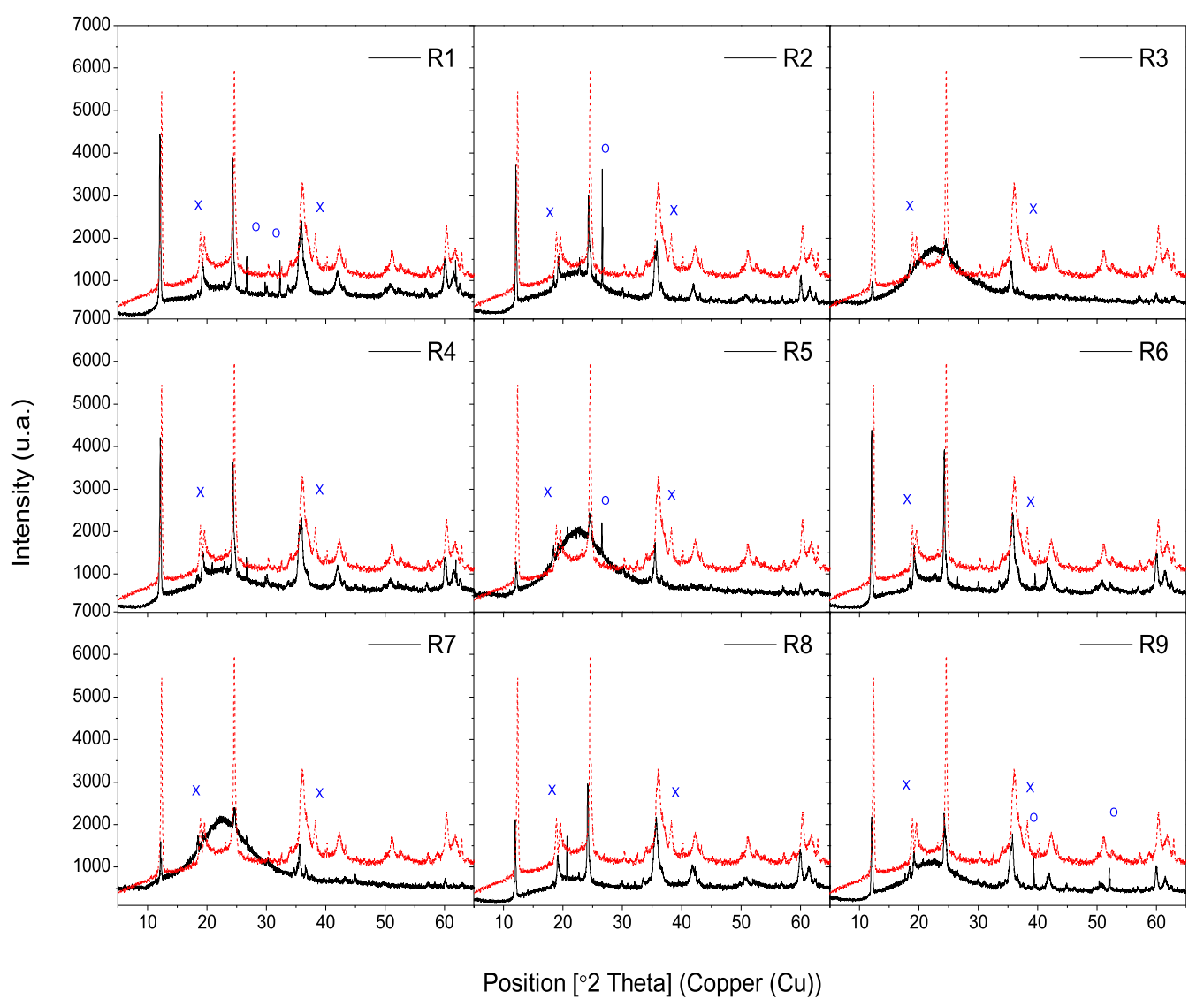

Fig. 9. X-Ray diffraction for S-GO and residues (R), for all experimental tests. $\mathrm{SiO}_{2}$ (o), chrysotile and brucite (X). 
clinochrysotile, showing a higher reactivity in comparison to lizardite $1 \mathrm{~T}$.

Native brucite is highly reactive, quickly dissolving during the first 5 min of leaching (Morgan, 1997). According to Assima et al. (2014), brucite dissolution in $\mathrm{H}_{2} \mathrm{O}$ is 10 times higher than dissolution of serpentines. However, chrysotile easily dissolves when compared to compact serpentines (lizardites/antigorites) due to its disorganized fiber structure, which facilitates diffusion of the leaching fluid.

During leaching of chrysotiles, which are more complex than brucites, the efficiency of $\mathrm{Mg}$ extraction is independent from the surface area $\left(\mathrm{S}_{\mathrm{BET}}\right)$, and it is related to their destructuring degree, types and size of fibers (Bloise et al., 2014; Morgan, 1997; Parry, 1985). The fiber type greatly depends on the replacement mechanism for cations in the chrysotile octahedral sheets $(0)$. The octahedral $\mathrm{Fe}^{2+}$ favors a maladjustment of fibers producing higher curvatures (Bloise et al., 2014; Wicks and Whittaker, 1975).

During this study, the $\mathrm{Fe}^{2+}$ found on clinochrysotile was located in the fiber external octahedral sheet. $\mathrm{Fe}^{3+}$ has little probability of being present in this sheet, replacing $\mathrm{Mg}^{2+}$, due to the maladjustment that clinochrysotiles need in order to obtain concentric structures (Wicks and Whittaker, 1975).

Fast dissolution of most clinochrysotile is also due to the milling process (mechanical activation) which caused a considerable reduction of fiber size, to the $10 \mu \mathrm{m}$ order (Fig. 10).

A fast dissolution of most clinochrysotile is also due to the milling process (mechanical activation) which caused a considerable reduction of fiber size, to the $10 \mu \mathrm{m}$ magnitude (Fig. 10). Although S-GO had few clinochrysotile fibers, these were totally destructured on extremes (red arrow). Thus, they were even more reactive, dissolving in low temperatures and concentrations.

On the other hand, lizardite $1 \mathrm{~T}$ has a resistance to dissolution due to the content of trivalent elements $\left(\mathrm{Al}^{3+}\right.$ and $\mathrm{Fe}^{3+}$ ) hosted in the tetrahedral and octahedral sheets, causing a higher stability in the crystalline structure. Thus, dissolution of lizardite 1T was possible only when the temperature was increased.

High Fe extraction in elevated temperatures $\left(100^{\circ} \mathrm{C}\right)$ was due to dissolution of most lizardite 1T. These are normally rich in $\mathrm{Fe}^{3+}$ (Wicks and Whittaker, 1975). This fact was not different in the case of lizardite 1T from S-GO. Previous analyses of rocks from Minaçu Mine confirmed a high $\mathrm{Fe}^{3+}$ content in this material (Barbosa and Bretas, 2009; Pereira, 2013). However, $\mathrm{Fe}^{3+}$ contained on lizardite $1 \mathrm{~T}$ do not produce a strong structural stability, since it is found in

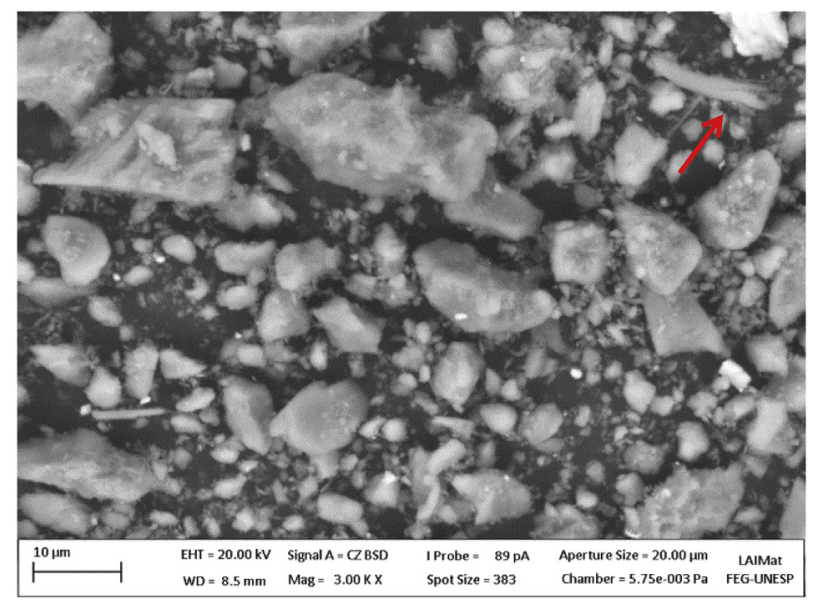

Fig. 10. Micrography for powder S-GO with $75 \mu \mathrm{m}$. Red arrows indicate short fibers of clinochrysotile. (For interpretation of the references to colour in this figure legend, the reader is referred to the web version of this article.) the octahedral sheet (Wicks and Whittaker, 1975). Such mineralogical characteristic increased S-GO reactivity, allowing higher amounts of $\mathrm{Mg}$ and Fe to be extracted.

When DTG peaks were observed for residues in the tests that employed temperatures of $100{ }^{\circ} \mathrm{C}(\mathrm{R} 3$, R5, and R7; Fig. 8), characteristic peaks for lizardite $1 \mathrm{~T}\left(659{ }^{\circ} \mathrm{C}\right)$ were less intense when compared to S-GO peaks from this region. However, it can be verified that brucite $\left(382^{\circ} \mathrm{C}\right)$ was not totally extracted. This fact was confirmed through diffractograms for residues R3, R5, and R7. Diffraction lines referring to lizardite $1 \mathrm{~T}$ have reduced intensity as observed on Fig. 9, however, diffraction lines due to brucite are still present in all of those diffractograms (in smaller intensity when compared to the S-GO diffractogram).

Taking all information into consideration, it can be said that an increase in temperature favored the dissolution of lizardite 1T. However, brucite reactivity seemed to decrease, not dissolving completely, as it happened at $25{ }^{\circ} \mathrm{C}$. The formation of a siloxane layer is expected in greater amount $(\mathrm{Si}-\mathrm{O}-\mathrm{Si})$ when lizardite 1T and clinochrysotile are dissolved, creating a limiting layer. Such layer limits acid diffusion processes within solid particles, causing blockage of pores and reducing the $\mathrm{Mg}$ and $\mathrm{Fe}$ extraction from internal layers (Kosuge et al., 1995; Morgan, 1997; Park and Fan, 2004).

Diffractograms from experiments which obtained higher $\mathrm{Mg}$ and Fe extraction from S-GO (R3, R5, and R7) are observed on Fig. 9. Such diffractograms show a curved trend in the first $40^{\circ}$ of the diffractograms. This indicates that serpentines modified their structure due to the formation of amorphous silica $\left(\mathrm{SiO}_{2}\right)$.

However, appearance of new diffraction lines (blue circle) was also observed in diffractograms for residues, which were sometimes very intense (R1 and R2) and other times were superimposed with amorphous material (R5 e R9). These diffraction lines are due to the presence of a better structured silica. Predominance of amorphous silica is of great industrial interest since it can be used as an additive for the cement industry and fertilizer for the agricultural sector. However, it must be further purified, by removing the magnetite present by magnetic separation, for example.

As observed on Fig. 8, a large part of both serpentines can be dissolved at $100{ }^{\circ} \mathrm{C}$. Thus, a large portion of $\mathrm{Mg}$ and $\mathrm{Fe}$ content can be taken out of the S-GO. In the same experimental test, part of the serpentine remained in the residue and did not react. Therefore, concentrations of $\mathrm{MgO}$ and $\mathrm{Fe}_{2} \mathrm{O}_{3}$ presented a similar trend, as verified by the XRF analysis from Table 7.

This trend indicates that large part of the $\mathrm{Fe}_{\mathrm{t}}$ in serpentines $\left(\mathrm{Fe}^{2+}\right.$ and $\mathrm{Fe}^{3+}$ ) might be found in octahedral sheets with $\mathrm{Mg}^{2+}$. It is expected that octahedral $\mathrm{Fe}^{2+}$ would replace octahedral $\mathrm{Mg}^{2+}$ in clinochrysotiles. Besides this, a large part of octahedral $\mathrm{Fe}^{3+}$ replaces octahedral $\mathrm{Mg}^{2+}$ in lizardite 1T. In this manner, when serpentines are dissolved, dissolution of the octahedral sheet simultaneously carry cations such as $\mathrm{Mg}^{2+}, \mathrm{Fe}^{3+}$, and $\mathrm{Fe}^{2+}$ towards the leaching solution.

Table 7

Chemical composition of residues determined by XRF.

\begin{tabular}{lllllllll}
\hline & $\mathrm{MgO}$ & $\mathrm{Fe}_{2} \mathrm{O}_{3}$ & $\mathrm{SiO}_{2}$ & $\mathrm{Al}_{2} \mathrm{O}_{3}$ & $\mathrm{Cr}_{2} \mathrm{O}_{3}$ & $\mathrm{CaO}$ & $\mathrm{MnO}$ & $\mathrm{NiO}$ \\
\hline $\mathrm{R} 1$ & 34.7 & 9.4 & 50.4 & 1.2 & 1.1 & 0.1 & 0.1 & 0.5 \\
$\mathrm{R} 2$ & 13.4 & 4.5 & 77.9 & 1.6 & 1.5 & 0.1 & 0.1 & 0.2 \\
$\mathrm{R} 3$ & 1.5 & 1.5 & 93.8 & 1.8 & 1.7 & 0.1 & 0.1 & n.d. \\
$\mathrm{R} 4$ & 21.8 & 7.8 & 66.1 & 1.7 & 1.4 & 0.1 & 0.1 & 0.4 \\
$\mathrm{R} 5$ & 2.8 & 2.0 & 91.5 & 1.3 & 1.8 & 0.1 & 0.1 & n.d. \\
$\mathrm{R} 6$ & 31.2 & 7.8 & 56.7 & 1.6 & 1.2 & 0.1 & 0.1 & 0.5 \\
$\mathrm{R} 7$ & 1.6 & 3.6 & 86.3 & 1.8 & 2.3 & 0.1 & 0.1 & 0.1 \\
$\mathrm{R} 8$ & 31.7 & 9.1 & 54.5 & 2.0 & 1.1 & 0.1 & 0.1 & 0.5 \\
$\mathrm{R} 9$ & 13.1 & 3.6 & 78.9 & 1.7 & 1.5 & 0.1 & 0.1 & 0.2 \\
\hline
\end{tabular}


On the other hand, large part of tetrahedral $\mathrm{Al}^{3+}$ is found replacing tetrahedral $\mathrm{Si}^{4+}$, mainly in lizardite $1 \mathrm{~T}$. Thus, when the acid $\left(\mathrm{H}^{+}\right)$breaks Van der Waals bonds between octahedral and tetrahedral sheets to form siloxanes, $\mathrm{Al}^{3+}$ is also encapsulated along with $\mathrm{Si}^{4+}$ which simultaneously collapse in the residues, forming amorphous material in a similar trend (Table 7).

Low $\mathrm{Al}^{3+}$ content in S-GO favored lizardite 1T dissolution, with increasing temperature. Although $\mathrm{Fe}^{3+}$ is found in the lizardite $1 \mathrm{~T}$ octahedral sheet to provide structural stability, this is not very effective, allowing Fe extraction then.

Taking all of this information into consideration, it is possible to conclude that hosting a large part of $\mathrm{Fe}\left(\mathrm{Fe}^{2+}\right.$ and $\left.\mathrm{Fe}^{3+}\right)$ favors extraction in lizardite 1T and clinochrysotile octahedral sheets, which adopt a similar behavior as the $\mathrm{Mg}$ extraction from the octahedral sheet (Park and Fan, 2004; Wicks and Whittaker, 1975).

In order to evaluate the Mg extraction behavior and structural modification of mineral phases during leaching, an experimental test was performed using T7 experimental conditions. This condition is the closest to be applied in industrial processes, due to the low acid concentration and stoichiometric mass/volume ratio $(1 \mathrm{M}$ $\mathrm{HCl}$ ), which would allow its recovery through the bipolar electrodialysis process in subsequent steps.

Aliquots were taken at every 30 min during the test, in which $200 \mathrm{~mL}$ of a $1 \mathrm{M} \mathrm{HCl}$ solution was employed. They were then filtered

(a)

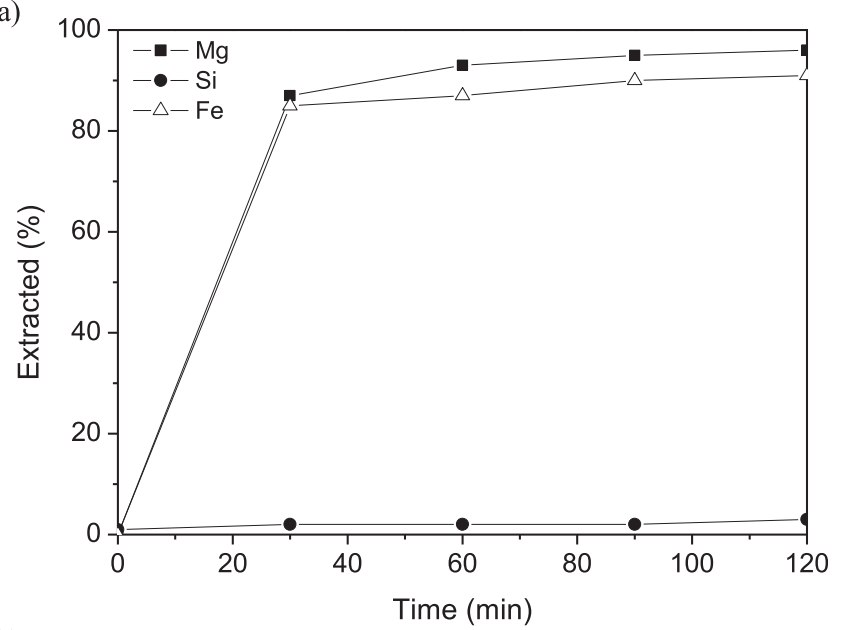

(b)

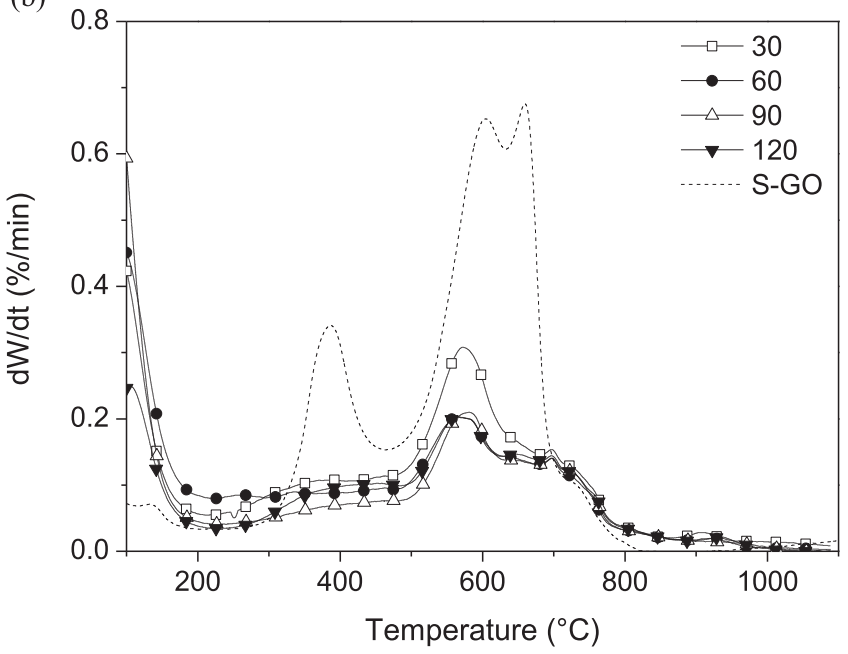

Fig. 11. Extraction curves and DTG for S-GO and residues, obtained from aliquots at every 30 min during $\mathrm{T} 7$ test. to obtain residues and leaching solutions, which were sent for TGA and ICP-OES analyses, respectively.

Fig. 11a presents extraction results for $\mathrm{Mg}$, Fe and $\mathrm{Si}$ at every 30 min. Almost $88 \pm 2 \%$ of $\mathrm{Mg}$ and Fe was extracted in the first $30 \mathrm{~min}$. In addition, $\mathrm{Mg}$ extraction was a lot faster than $\mathrm{Si}$, which kept an almost constant value during the reaction time.

Fig. 11b presents DTG curves for S-GO and residues obtained at every $30 \mathrm{~min}$. It can be observed that all brucite, along with a significant part of lizardite 1T and clinochrysotile reacted with $\mathrm{HCl}$ during the first $30 \mathrm{~min}$. Variation of DTG curves were minimum after $1 \mathrm{~h}$ of reaction. A high reactivity for brucite, destructured fibers from clinochrysotile, low $\mathrm{Al}^{3+}$ tetrahedral and high $\mathrm{Fe}_{\mathrm{t}}$ octahedral contents for both serpentines were factors that favored $\mathrm{Mg}$ and Fe extraction from S-GO. Reduction of the reaction time reduces the residence time within the reactor, which could minimize costs involved with the $\mathrm{pH}$ swing method (Bu et al., 2012; House et al., 2007; Teir et al., 2007a; 2007b).

Few studies were performed regarding indirect mineral carbonation through $\mathrm{pH}$ swing processes employing serpentinite rocks that have brucite contents. According to Assima et al. (2013), serpentinite rocks that contain brucite and compact serpentines (lizardite/antigorite) are not very appropriate for use in direct carbonation, due to the difficulty of controlling $\mathrm{pH}$ because of a high Fe content in this type of serpentine.

Based on results verified during this study, this behavior does not seem to apply when serpentinite rocks containing lizardite $1 \mathrm{~T}$ mixed with native brucite are used in indirect mineral carbonation. The brucite content significantly improved characteristics for S-GO serpentinite rock. In addition, brucite contents in the material delayed the formation of a silica gel layer, due to the fast brucite extraction, leaving a material with higher contact surface, so that the acid had more contact with serpentines. $\mathrm{HCl}$ reacted by breaking Van Der Waals bonds between serpentine octahedral and tetrahedral sheets, quickly dissolving them. However, it must be mentioned that this behavior could be limited to high tetrahedral $\mathrm{Al}^{3+}$ and $\mathrm{Fe}^{3+}$ contents in lizardites 1T (Lacinska et al., 2016), which was not characteristic for S-GO.

\section{Conclusions}

This study investigated the adaptability of using a sterile (S-GO) for indirect carbonation processes through the $\mathrm{pH}$ swing method. In order to accomplish that, the most critical process step was evaluated, in which $\mathrm{Mg}$ and Fe were extracted during the leaching process.

According to the results obtained in this study, S-GO was revealed as a rock with adequate characteristics to be employed in leaching processes, although lizardite $1 \mathrm{~T}$ was identified as the main mineral phase from this rock. It was demonstrated that native brucite $(6.10 \pm 0.24 \%)$, low tetrahedral $\mathrm{Al}^{3+}$ content, as well as $\mathrm{Fe}^{2+}$ and $\mathrm{Fe}^{3+}$ contents within S-GO octahedral sheets, delay the formation of hydrated silica and improve dissolution of serpentines. $\mathrm{Mg}$ and Fe extractions in larger size particles $(300 \mu \mathrm{m})$ were more efficient than other results reported in the literature. Thus, the appropriate particle size will be a function of the material chemical characteristics, mainly its mineralogical complexity and crystal chemistry. An excess of acid only improves $\mathrm{Mg}$ and Fe extraction by $10 \pm 5 \%$, for this kind of material.

These S-GO characteristics allowed a high dissolution of mineral phases. Thus, $88 \pm 2 \%$ of $\mathrm{Mg}$ and Fe was extracted during the first $30 \mathrm{~min}$ of reaction under mild process conditions, such as: use of stoichiometric mass/volume ratio, $1 \mathrm{M} \mathrm{HCl}, 1$ bar of pressure, $100^{\circ} \mathrm{C}$ process temperature, and $300 \mu \mathrm{m}$ particle size. It must be emphasized that this type of material might have the same behavior when used with other leaching agents, such as $\mathrm{NH}_{4} \mathrm{HSO}_{4}$. 
Such characteristics reduce energetic penalties during these processes. The costs generated during milling are smaller when compared to $\mathrm{HCl}$ regeneration. However, results showed that even when higher granulometries are used $(300 \mu \mathrm{m})$, high $\mathrm{Mg}$ and $\mathrm{Fe}$ extractions were obtained, which would lead to lower energy consumption in the milling step. In addition, high extractions were verified when stoichiometric amounts were employed, reducing the energy consumption in subsequent steps of $\mathrm{HCl}$ regeneration and minimizing energetic penalties involved in these processes. A stoichiometric proportion can also decrease the costs related to the total number of reactors used in the leaching step. However, deeper energetic consumption evaluations using bipolar electrodialysis could be evaluated in further studies.

Finally, the experimental planning was found to be appropriate to evaluate several factors and levels which affect the response variable, that was the extraction of $\mathrm{Mg}$ and $\mathrm{Fe}$ in this case. Thus, the L9 arrangement used to evaluate three factors and three different levels was considered useful, since several pieces of information were obtained with 10 experimental tests in order to maximize response variables. Evaluations of the best reaction condition, construction of polynomials, and response surfaces will need to be studied in the future.

\section{Acknowledgements}

The authors would like to acknowledge FAPESP for postdoctorate project number 2013/21244-5 and CNPq for project number 150894/2014-7 which supported this study. In addition, Mineração Associada (SAMA S.A.) that provided the material for this study is also acknowledged. The authors also thank the laboratory coworkers: LCP/INPE in Cachoeira Paulista, Dr. Okamoto Sayuri; COPPE/UFRJ in Rio de Janeiro, Dr. Carlos André de Castro Perez.

\section{References}

Alves, N., Xavier, C., Dullius, J., Ligabue, R., Ketzer, J.M., Seferin, M., Einloft, S., 2013. Potential use of serpentinite for $\mathrm{CO}_{2}$ mineral storage. Quim Nova 36, 773-777. http://dx.doi.org/10.1590/S0100-40422013000600005.

Arce, G.L.A.F., Carvalho Jr., J.A., Nascimento, L.F.C., 2014. A time series sequestration and storage model of atmospheric carbon dioxide. Ecol. Modell. 272, 59-67. http://dx.doi.org/10.1016/j.ecolmodel.2013.09.006.

Assima, G.P., Larachi, F., Beaudoin, G., Molson, J., 2012. CO $\mathrm{CO}_{2}$ sequestration in chrysotile mining residues-implication of watering and passivation under environmental conditions. Ind. Eng. Chem. Res. 51, 8726-8734. http://dx.doi.org/ $10.1021 /$ ie202693q.

Assima, G.P., Larachi, F., Molson, J., Beaudoin, G., 2014. Comparative study of five Québec ultramafic mining residues for use in direct ambient carbon dioxide mineral sequestration. Chem. Eng. J. 245, 56-64. http://dx.doi.org/10.1016/ j.cej.2014.02.010.

Assima, G.P., Larachi, F., Molson, J., Beaudoin, G., 2013. Accurate and direct quantification of native brucite in serpentine ores New methodology and implications for $\mathrm{CO}_{2}$ sequestration by mining residues. Thermochim. Acta 566, 281-291. http://dx.doi.org/10.1016/j.tca.2013.06.006.

Azdarpour, A., Asadullah, M., Mohammadian, E., Hamidi, H., Junin, R., Karaei, M.A. 2015. A review on carbon dioxide mineral carbonation through $\mathrm{pH}$-swing process. Chem. Eng. J. 279, 615-630. http://dx.doi.org/10.1016/j.cej.2015.05.064.

Balucan, R.D., Dlugogorski, B.Z., Kennedy, E.M., Belova, I.V., Murch, G.E., 2013. Energy cost of heat activating serpentinites for $\mathrm{CO}_{2}$ storage by mineralisation. Int. J. Greenh. Gas. Control 17, 225-239. http://dx.doi.org/10.1016/ j.ijggc.2013.05.004.

Barbosa, O.F.-F., Bretas, W.L., 2009. Economia Mineral Do Brasil. DNPM - Departamento Nacional de Produção Mineral, Brasilia DF, pp. 655-679.

Basta, E.Z., Kader, Z.A., 1969. The mineralogy of egyptian serpentinites and talccarbonates. Mineral. Mag. 37, 394-408. http://dx.doi.org/10.1180/ minmag.1969.037.287.13.

Baumeister, J.L., 2012. Chemical Weathering of the Mafic Minerals Serpentine and Olivine in Natural Environments. University of Nevada. Master Thesis.

Björklöf, T., Zevenhoven, R., 2012. Energy efficiency analysis of $\mathrm{CO}_{2}$ mineral sequestration in magnesium silicate rock using electrochemical steps. Chem Eng. Res. Des. 90, 1467-1472. http://dx.doi.org/10.1016/j.cherd.2012.02.001.

Bloise, A., Critelli, T., Catalano, M., Apollaro, C., Miriello, D., Croce, A., Barrese, E., Liberi, F., Piluso, E., Rinaudo, C., Belluso, E., 2014. Asbestos and other fibrous minerals contained in the serpentinites of the Gimigliano-Mount Reventin
Unit (Calabria, S-Italy). Environ. Earth Sci. 71, 3773-3786. http://dx.doi.org/ 10.1007/s12665-013-3035-2.

Bu, J., Bai, P., Sharratt, P., 2012. Carbon Dioxide Capture with Regeneration of Salt. International Publication Number WO 2012/050530 A1.

Caruso, L.J., Chernosky, J.V.J., 1979. The stability of lizardite. Can. Mineral. 17, 757-769.

Chamley, H., 1989. Clay Sedimentology, Katalog BPS. Springer, New York. http:// dx.doi.org/10.1007/s13398-014-0173-7.2.

Daval, D., Hellmann, R., Martinez, I., Gangloff, S., Guyot, F., 2013. Lizardite serpentine dissolution kinetics as a function of $\mathrm{pH}$ and temperature, including effects of elevated $\mathrm{pCO}_{2}$. Chem. Geol. 351, 245-256. http://dx.doi.org/10.1016/ j.chemgeo.2013.05.020.

Dlugogorski, B.Z., Balucan, R.D., 2014. Dehydroxylation of serpentine minerals: implications for mineral carbonation. Renew. Sustain Energy Rev. 31, 353-367. http://dx.doi.org/10.1016/j.rser.2013.11.002.

Evans, B.W., 2008. Control of the products of serpentinization by the $\mathrm{Fe}^{2+} \mathrm{Mg}^{-1}$ exchange potential of olivine and orthopyroxene. J. Pet. 49, 1873-1887. http:// dx.doi.org/10.1093/petrology/egn050.

Földvári, M., 2011. Handbook of the Thermogravimetric System of Minerals and its Use in Geological Practice. http://dx.doi.org/10.1556/CEuGeol.56.2013.4.6. Central European Geology. Budapest.

Frost, R.B., Beard, J.S., 2007. On silica activity and serpentinization. J. Pet. 48, 1351-1368. http://dx.doi.org/10.1093/petrology/egm021.

Habashi, F., 2002. Asbestos. In: Buschow, KHJ, Cahn, R., Flemings, M., Ilschner, B., Kramer, E., Mahajan, S., et al. (Eds.), Encyclopedia of Materials: Science and Technology. Elsevier, Waltham, MA, pp. 1-5. http://dx.doi.org/10.1016/B0-08043152-6/01848-9.

Harrison, A.L., Power, I.M., Dipple, G.M., 2013. Accelerated carbonation of brucite in mine tailings for carbon sequestration. Environ. Sci. Technol. 47, 126-134. http://dx.doi.org/10.1021/es3012854.

Hemmati, A., Shayegan, J., Bu, J., Yeo, T.Y., Sharratt, P., 2014a. Process optimization for mineral carbonation in aqueous phase. Int. J. Min. Process 130, 20-27. http://dx.doi.org/10.1016/j.minpro.2014.05.007.

Hemmati, A., Shayegan, J., Sharratt, P., Yeo, T.Y., Bu, J., 2014b. Solid products characterization in a multi-step mineralization process. Chem. Eng. J. 252, 210-219. http://dx.doi.org/10.1016/j.cej.2014.04.112.

Highfield, J., Lim, H., Fagerlund, J., Zevenhoven, R., 2012. Activation of serpentine for $\mathrm{CO}_{2}$ mineralization by flux extraction of soluble magnesium salts using ammonium sulfate. RSC Adv. 2, 6535-6541. http://dx.doi.org/10.1039/ c2ra01347a.

Hostetler, P.B., Coleman, R.G., Mumpton, F.A., 1966. Brucite in Alpine serpentinites Am. Mineral. 51, 74-98. http://dx.doi.org/10.1163/_q3_SIM_00374.

House, K.Z., House, C.H., Schrag, D.P., Aziz, M.J., 2007. Electrochemical Acceleration of chemical weathering as an energetically feasible Approach to mitigating anthropogenic climate change. Environ. Sci. Technol. 41, 8464-8470.

Kosuge, K., Shimada, K., Tsunashima, A., 1995. Micropore formation by acid treatment of antigorite. Chem. Mater 7, 2241-2246. http://dx.doi.org/10.1021/ cm00060a009.

Lacinska, A.M., Styles, M.T., Bateman, K., Wagner, D., Hall, M.R., Gowing, C., Brown, P.D., 2016. Acid-dissolution of antigorite, chrysotile and lizardite for ex situ carbon capture and storage by mineralisation. Chem. Geol. 437, 153-169. http://dx.doi.org/10.1016/j.chemgeo.2016.05.015.

Lavikko, S., Eklund, O., 2016. The significance of the serpentinite characteristics in mineral carbonation by “the Å Route. Int. J. Min. Process 152, 7-15. http:// dx.doi.org/10.1016/j.minpro.2016.04.009.

Li, J., Dong, Q., Yu, K., Liu, L., 2014. Asbestos and asbestos waste management in the Asian-Pacific region: trends, challenges and solutions. J. Clean. Prod. 81, 218-226. http://dx.doi.org/10.1016/j.jclepro.2014.06.022.

Lima, T.M., 1997. Geologia, Estratigrafia e petrologia da porção sul do complexo máfico-ultramáfico de cana brava, Goiás. Universidade de Brasília. Dissertation.

Mangindaan, D.W., Woon, N.M., Shi, G.M., Chung, T.S., 2015. P84 polyimide membranes modified by a tripodal amine for enhanced pervaporation dehydration of acetone. Chem. Eng. Sci. 122, 14-23. http://dx.doi.org/10.1016/ j.ces.2014.09.014.

Maroto-Valer, M., Kuchta, M., 2004. Comparison of physical and chemical activation of serpentine for enhanced $\mathrm{CO}_{2}$ sequestration. Prepr. Pap. Am. Chem. 2, $373-375$.

McCutcheon, J., Dipple, G.M., Wilson, S.A., Southam, G., 2015. Production of magnesium-rich solutions by acid leaching of chrysotile: a precursor to fieldscale deployment of microbially enabled carbonate mineral precipitation. Chem. Geol. 413, 119-131. http://dx.doi.org/10.1016/j.chemgeo.2015.08.023.

Mellini, M., 1982. The crystal structure of lizardite 1T: hydrogen bonds and polytypism. Am. Mineral. 67, 587-598.

Morgan, A., 1997. Acid leaching studies of chrysotile asbestos from mines in the Coalinga region of California and from Quebec and British Columbia. Ann. Occup. Hyg. 41, 249-268. http://dx.doi.org/10.1016/S0003-4878(97)00001-X.

Nam, S.N., Jeong, S., Lim, H., 2014. Thermochemical destruction of asbestoscontaining roofing slate and the feasibility of using recycled waste sulfuric acid. J. Hazard Mater 265, 151-157. http://dx.doi.org/10.1016/ j.jhazmat.2013.11.004.

Oskierski, H.C., Dlugogorski, B.Z., Jacobsen, G., 2013. Sequestration of atmospheric $\mathrm{CO}_{2}$ in a weathering-derived, serpentinite-hosted magnesite deposit: $14 \mathrm{C}$ tracing of carbon sources and age constraints for a refined genetic model. Geochim. Cosmochim. Acta 122, 226-246. http://dx.doi.org/10.1016/ j.gca.2013.08.029. 
1336

G.L.A.F. Arce et al. / Journal of Cleaner Production 141 (2017) 1324-1336

Park, A.-H.A., Fan, L.-S., 2004. $\mathrm{CO}_{2}$ mineral sequestration: physically activated dissolution of serpentine and pH swing process. Chem. Eng. Sci. 59, 5241-5247. http://dx.doi.org/10.1016/j.ces.2004.09.008.

Parry, W.T., 1985. Calculated solubility of chrysotile asbestos in physiological systems. Environ. Res. 37, 410-418. http://dx.doi.org/10.1016/0013-9351(85) 90122-7.

Pereira, G.A., 2013. Crisotila amianto. In: Sumário Mineral Do Departamento Nacional de Produção Mineral, pp. 2012-2013 [In Portugues].

Putnis, A., 2003. Introduction to Mineral Science. Cambridge University Press, United States of America.

Sanna, A., Dri, M., Hall, M.R., Maroto-Valer, M., 2012. Waste materials for carbon capture and storage by mineralisation (CCSM) - a UK perspective. Appl. Energy 99, 545-554. http://dx.doi.org/10.1016/j.apenergy.2012.06.049.

Sanna, A., Lacinska, A., Styles, M., Maroto-Valer, M.M., 2014a. Silicate rock dissolution by ammonium bisulphate for $\mathrm{pH}$ swing mineral $\mathrm{CO}_{2}$ sequestration. Fue Process Technol. 120, 128-135. http://dx.doi.org/10.1016/j.fuproc.2013.12.012.

Sanna, A., Uibu, M., Caramanna, G., Kuusik, R., Maroto-Valer, M.M., 2014b. A review of mineral carbonation technologies to sequester $\mathrm{CO}_{2}$. Chem. Soc. Rev. http:// dx.doi.org/10.1039/c4cs00035h.

Sanna, A., Wang, X., Lacinska, A., Styles, M., Paulson, T., Maroto-Valer, M.M., 2013. Enhancing $\mathrm{Mg}$ extraction from lizardite-rich serpentine for $\mathrm{CO}_{2}$ mineral sequestration. Min. Eng. 49, 135-144. http://dx.doi.org/10.1016/j.mineng.2013.05.018.

Stewart, I.M., Putscher, R.E., Humecki, H.J., Shimps, R.J., 1977. Asbestos Fibers in Discharges from Selected Mining and Milling Activities. U.S. Environmental Protection agency (EPA) office of toxic substances.

Teir, S., Eloneva, S., Fogelholm, C., Zevenhoven, R., 2009. Fixation of carbon dioxide by producing hydromagnesite from serpentinite. Appl. Energy 86, 214-218. http://dx.doi.org/10.1016/j.apenergy.2008.03.013.

Teir, S., Kuusik, R., Fogelholm, C., Zevenhoven, R., 2007a. Production of magnesium carbonates from serpentinite for long-term storage of $\mathrm{CO}_{2}$. Int. J. Min. Process
85, 1-15. http://dx.doi.org/10.1016/j.minpro.2007.08.007.

Teir, S., Revitzer, H., Eloneva, S., Fogelholm, C.-J., Zevenhoven, R., 2007b. Dissolution of natural serpentinite in mineral and organic acids. Int. J. Min. Process 83, 36-46. http://dx.doi.org/10.1016/j.minpro.2007.04.001.

Trittschack, R., Grobéty, B., Brodard, P., 2014. Kinetics of the chrysotile and brucite dehydroxylation reaction: a combined non-isothermal/isothermal thermogravimetric analysis and high-temperature X-ray powder diffraction study. Phys. Chem. Min. 41, 197-214. http://dx.doi.org/10.1007/s00269-013-0638-9.

Valouma, A., Verganelaki, A., Maravelaki-kalaitzaki, P., Gidarakos, E., 2016. Chrysotile asbestos detoxification with a combined treatment of oxalic acid and silicates producing amorphous silica and biomaterial. J. Hazard Mater 305, $164-170$.

Van Essendelft, D.T., Schobert, H.H., 2009. Kinetics of acid digestion of serpentine with concurrent grinding. 1. Initial investigations. Ind. Eng. Chem. Res. 48, 2556-2565.

Viti, C., 2010. Serpentine minerals discrimination by thermal analysis. Am. Mineral. 95, 631-638. http://dx.doi.org/10.2138/am.2010.3366.

Wang, X., Maroto-valer, M.M., 2011. Dissolution of serpentine using recyclable ammonium salts for $\mathrm{CO}_{2}$ mineral carbonation. Fuel 90, 1229-1237. http:// dx.doi.org/10.1016/j.fuel.2010.10.040.

Weber, J.N., Greer, R.T., 1965. Dehydration of serpentine: heat of reaction and reaction kinetics at $\mathrm{Ph}_{2} \mathrm{O}=1$ Atm. Am. Mineral. 50, 450-464.

Wicks, F.J., Whittaker, E.J.W., 1975. A reappraisal of the structures of the serpentine minerals. Can. Mineral. 13, 227-243.

Yu, J., Wang, K., 2011. Study on characteristics of steel slag for $\mathrm{CO}_{2}$ capture. Energy \& Fuels 25, 5483-5492. http://dx.doi.org/10.1021/ef2004255.

Yuan, B., Yu, Q.L., Brouwers, H.J.H., 2015. Reaction kinetics, reaction products and compressive strength of ternary activators activated slag designed by Taguchi method. Mater Des. 86, 878-886. http://dx.doi.org/10.1016/j. matdes.2015.07.077. 